\title{
BNWL-109
}

\section{PRTR CONTAINMENT VESSEL PRESSURE TEST EXPERIENCE}

\section{DEVELOPMENT REPORT}

\author{
R. G. CLARK and D. R. KOBERG
}

AUGUST, 1965

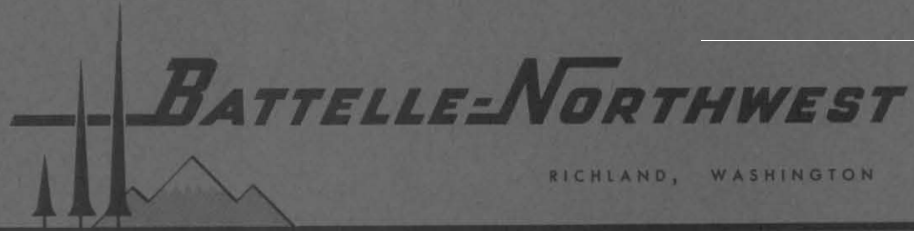

PACIFIC NORTHWEST LABORATORY operated by BATTELLE MEMORIAL INSTITUTE 


\section{LEGAL NOTICE}

This report was prepared as an account of Government sponsored work. Neither the United States, nor the Commission, nor any person acting on behalf of the Commission:

A. Makes any warranty or representation, expressed or implied, with respect to the accuracy, completeness, or usefulness of the information contained in this report, or that the use of any information, apparatus, method, or process disclosed in this report may not infringe privately owned rights; or

B. Assumes any liabilities with respect to the use of, or for damages resulting from the use of any information, apparatus, method, or process disclosed in this report.

As used in the above, "person aciing on behalf of the Commission" includes any employee or contractor of the Commission, or employee of such contractor, to the extent that such employee or contractor of the Commission, or employee of such contractor prepares, disseminates, or provides access to, any information pursuant to his employment or contract with the Commission, or his employment with such contractor.

\section{PACIFIC NORTHWEST LABORATORY \\ RICHLAND, WASHINGTON \\ operated by \\ BATTELLE MEMORIAL INSTITUTE}

for the

UNITED STATES ATOMIC ENERGY COMMISSION UNDER CONTRACT AT(45-1)-1830 


\section{8}

BNWL-109

UC-80, Reactor

Technology

PRTR CONTAINMENT VESSEL PRESSURE TEST EXPERIENCE

by

R. G. Clark

and

D. R. Koberg

PRTR Section

Test Reactor and Engineering Services

August, 1965

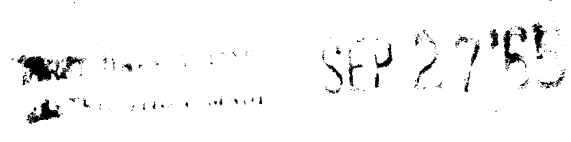

PACIFIC NORTHWEST LABORATORY

RICHLAND, WASHINGTON 
Printed in USA. Price $\$ 3.00$. Available from the Clearinghouse for Federa1 Scientific and Technical Information, National Bureau of Standards

U. S。 Department of Commerce, Springfield, Virginia 


\section{TABLE OF CONTENTS}

INTRODUCTION . . . . . . . . . . . . . . . . . . . . 1 SUMMARY. . . . . . . . . . . . . . . . . . . 2 ADVANCE PREPARATIONS . . . . . . . . . . . . . . . . 3 METHOD AND MEASUREMENTS. . . . . . . . . . . . . . . 5

1. Method. . . . . . . . . . . . . . . . 5

2. Reference Volume Design . . . . . . . . . 6

3. Vessel Pressure . . . . . . . . . . . . 8

4. Differential Pressure . . . . . . . . . . . . 8

5. Vapor Pressure. . . . . . . . . . . . . . 9

6. Vessel Temperature. . . . . . . . . . . . 10 PROCEDURES . . . . . . . . . . . . . . . . . . . . . 13

1. Pressurization. . . . . . . . . . . . . .13

2. Vessel Ventilation. . . . . . . . . . . . .13

3. Moisture Control. . . . . . . . . . . . . .14

4. Test Conditions . . . . . . . . . . . . . . 15

5. Data Handling. . . . . . . . . . . . . . .17 LOCAL LEAK DETECTION METHODS . . . . . . . . . . . . . 18 TEST EXPERIENCE. . . . . . . . . . . . . . . . . . . . . 19

Test 1........................ . . . . .

Test 2. . . . . . . . . . . . . . . . . .21

Test 3....................... . . . . . 22

Test 4...................... . . . 22

Test 5...................... . . . . . 5 FINAL TEST RESULTS . . . . . . . . . . . . . . 28 COMMENTS ON TESTING. . . . . . . . . . . . . . . . . . 29 


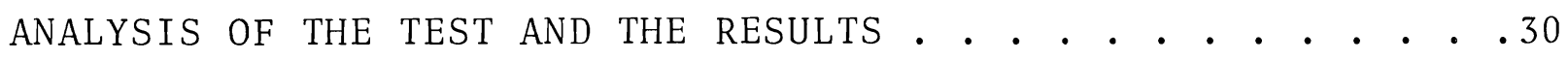

1. Corrections . . . . . . . . . . . . . . . . . . . . . . .

2. Expected Error. . . . . . . . . . . . . . . . . 32

3. Extrapolating Leakage Rates . . . . . . . . . . . . . 36

4. Checking the Method . . . . . . . . . . . . . 39

5. Comparison of Test Methods. . . . . . . . . . . . . 41

6. The Significance of Vapor Pressure Measurements • . . .44

CONCLUSIONS. . . . . . . . . . . . . . . . . . . . 45

ACKNOWLEDGMENTS. • • • • • • • • • • • • • . • • • • • • • • 49

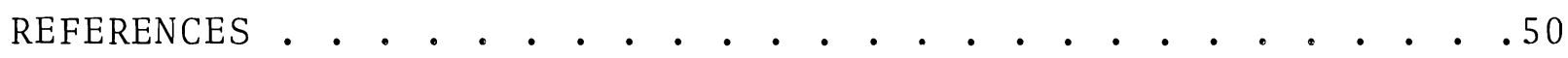

APPENDICES . • . . . . . . . . . . . . . . . . . . . . 51

I Instrumentation. . . . . . . . . . . . . . . . . 51

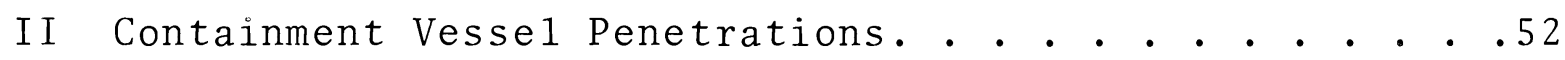

II Development of the Expression for Leakage Rate . . . . .54

IV Correction Factor for the Observed Differential

Pressure................... . . . . 58

V Data Sheet-Final Test. . . . . . . . . . . . . . . 60

VI Leakage Rate Calculations Final Test . . . . . . . . . . 62 


\section{LIST OF FIGURES}

Figure 1 Ambient and Vesse1 Conditions . . . . . . . . . . . 16

Figure 2 Superimposed Outflow Rate . . . . . . . . . . . 40

Figure 3 Reference Volume vs. Absolute Method-

Leakage Rate-Final Test. . . . . . . . 43

Figure 4 Leakage Rates and Differential Pressures from

15 Minute Periods... . . . . . . . . 46

Figure 5 Penetration Designs PRTR Containment Vesse1 • . . 53 


\section{LIST OF TABLES}

Table I Thermocouple Calibration . . . . . . . . . 12 Table II Test 1 Results . . . . . . . . . . . . 20 Table III Test 2 Results . . . . . . . . . . . . 23 Table IV Test 3 Results................. 24 Table V Test 4 Results................ 26 Table VI Test 5 Results................ 27 Table VII Final Test Results . . . . . . . . . . . 28 Table VIII Expected Errors in Measurement . . . . . . . . 34 Table IX Comparison of Proportionality Rules. . . . . . . 38 Table X Comparison of Leakage Rate Determination Methods . . 42 Table XI Summary of Statistical Analysis of Leakage Rates . . 47 
BNWL- 109

PRTR CONTAINMENT VESSEL PRESSURE TEST EXPERIENCE

INTRODUCTION

The leakage rate from the containment vessel housing the Plutonium Recycle Test Reactor (PRTR) was determined with a series of tests conducted at nominal pressures of 3,6 , and 15 psig during the latter half of May, 1964. Five years earlier, in May, 1959, shortly after construction was complete the unequipped containment vessel, containing about 440,000 $\mathrm{ft}^{3}$ of free space, had been tested successfully for leakage at the design pressure of 15 psig by the contractor. The leakage rate at that time which evaluated the welded structure and the two personnel airlock penetrations only, had been measured to be less than $0.05 \%$ per $24 \mathrm{hr}$.

In the intervening five years, the building has been equipped; vessel penetrations have been made for electrical, instrument, and pneumatic leads; and the containment valves and vacuum relief valves have been installed and used. Two leak detection tests had been conducted in these intervening years in which the vesse 1 was pressurized to 2.5 psig and the penetrations checked individually for leakage. (2) Because no evaluation of the overall integrity of the containment vessel at the design pressure had been made since the vessel had been equipped and the penetrations utilized and because a potted penetration failed during a test at $21 / 2$ psig conducted in 1963, a leakage rate test to be conducted at a higher pressure seemed appropriate.

An analysis of the radiological consequences of a reactor accident indicated that a $1 \%$ leakage rate by weight of the vesse 1 contents per $24 \mathrm{hr}$ at an internal pressure of $15 \mathrm{psig}$ 
was the maximum which could be tolerated." This leakage rate was established in the Operating Safety Limits prescribed by the Atomic Energy Commission for the reactor.

SUMMARY

A leakage rate of slightly less than $0.9 \%$ per. $24 \mathrm{hr}$ at the design pressure (15 psig) was determined for the containment vessel at PRTR. The results were obtained in a series of tests completed in May, 1964, using the Reference Volume Method in which $475 \mathrm{ft}$ of $\frac{3}{4}$ in. thin-walled copper tubing constituted the reference volume.

Results from tests conducted at 3,6 , and 15 psig showed that the leakage rates on this vessel at different pressures varied approximately as the square roots of the ratios of the gage pressures.

The test installation and the method of testing were verified by superimposing a $0.9 \%$ leakage rate on the vessel having an existing leakage rate of $1.3 \%$. The superimposed leakage rate was measured by a rotameter. The measured leakage rate increased from 1.3 to $2.1 \%$, giving an $0.8 \%$ increase.

Comparisons of leakage rates determined by the Absolute Method and the Reference Volume Method showed agreement within the limits of the errors inherent in the testing on all tests completed at different pressures.

The resolution of the differential pressure manometer and the stable temperatures and vapor pressures in the vessel during the testing permitted reliable estimates of leakage rates (based on a $24 \mathrm{hr}$ interva1), to be determined in tests as short as 3 to

\footnotetext{
* One percent per $24 \mathrm{hr}$ at $15 \mathrm{psig}$ has been interpreted to mean 8,000 scf per $24 \mathrm{hr}$ as the vessel now contains about $400,000 \mathrm{ft}^{3}$ of free space.
} 
15 min at the magnitude of the leakage rates measured in these tests. Leakage rate tests, it was shown, need not extend through $24 \mathrm{hr}$ periods and longer to provide reliable results.

ADVANCE PREPARATIONS

The PRTR was not designed to permit containment vesse1 pressure tests with all systems in operating order. When the vesse1 is pressurized, almost all pneumatic signals to the control room increase in psig readout the same amount as the vesse1 pressure. Most of these signals are important to reactor safety, and their loss would be critical. A necessary preliminary for safely pressure-testing the vessel, then, was discharging the reactor.

Extensive preparations and advanced testing were done to prevent damage to equipment or systems by pressures above 5 psig. Several of the tanks and vessels were not designed to withstand external pressure; they were vented by removing ruptured discs or otherwise breaking into the systems. Heavy water drums were either left open, if empty, or removed from the containment vesse1. Some of the pneumatic instrument transmitters were vented to prevent actuating bellows collapse.

Considerable electronic equipment is located in the containment vesse1, as well as fluorescent, incandescent, and mercury vapor lamps. Tests were conducted on all items of this nature at 18 psig pressure. (3) None of the tested items was affected by this external pressure: therefore, the installed equipment was left in place. Al1 remote area monitoring radiation chambers were removed from the vessel because of their sealed chamber design. Reactor flux chambers were left in place because they were known to undergo external pressure tests to $25 \mathrm{psig}$ during fabrication. Portable electronic equipment was removed from the vesse1 as a routine precaution. 
Two vacuum breakers on the containment vessel were known to leak slightly in previous tests. Also on previous pressure tests, the seals on the personnel and emergency airlock doors were observed to leak between the inflatable rubber seal and the metal seal face. These locations and other similar mechanical seal closures were inspected, repaired if necessary, and put in best possible working order. The underwater fuel transfer gate (sluice gate), which permits transfer of irradiated fuel from the containment vessel to the fuel storage basin, was checked for adjustment according to original vendor instructions.

At this stage, the reactor was in shutdown status and al1 irradiated fuel was transferred out of the containment vessel to the storage basin. The primary coolant system was drained in preparation for planned modification work not related to the containment vessel pressure test. Because all pneumatic control valves were to be deactivated the emergency light water injection system was blanked off to prevent ordinary water from entering the heavy water coolant piping.

The compressed air and instrument air lines were disconnected at the containment vessel flange penetrations; the penetrations were then sealed with blank flanges. The helium system was deactivated in a similar manner. The idle gas loop was pressurized to values slightly in excess of the planned vessel test pressures, using $\mathrm{CO}_{2}$ to protect the loop against gross exposure to air. All compressed gas cylinders installed in the vesse 1 were valved off, and the gage readings were recorded to assure test accuracy.

Safety rules for the test had been established previously and reviewed with all test personnel. Special safety zoning was placed in effect when the first test pressure was applied. 
METHOD AND MEASUREMENTS

1. Method

The Reference Volume Method was used to estimate the leakage rate. The development and use of this method has been extensively reported $(4,5,6)$ and it has been used to measure leakage rates on several containment vessels. (5, p.7-83)

The method involves three pressure measurements: gage vessel pressure, barometric pressure, and the differential pressure. The gage and barometric pressures are combined to give vessel pressure in absolute units. The differential pressure develops between the reference volume and the large containment vesse1.

These measurements can be easily made with high precision; and with ordinary care, they can be representative of large volumes. The accuracy inherent in this feature provides part of the incentive for using the reference volume method.

Temperature measurements of the contents of the same large volumes were included, but these are not required nor used in the evaluation of the leakage rate (see Appendix III). The inaccuracy in the estimate of the leakage rate that results from the unavoidable error in estimating average temperatures of extremely large volumes is avoided in the Reference Volume Method. This method assumes that reasonable care is given to the design and installation of the reference volumes so that at all times the temperatures of the contents of the reference volume and the large containment vessel can be assumed to be in equilibrium.

The changes in the partial pressure of water vapor in the vessel during the tests were included in the evaluation of 
the leakage rate. Changes in water vapor pressure, it will be shown, can be a source of considerable error if ignored or if inadequately determined.*

\section{Reference Volume Design}

The reference volume consisted of $475 \mathrm{ft}$ of $3 / 4$ in. copper tubing with a wall thickness of 0.035 in., which is referred to commercially as thin-walled tubing. It was designed this way because of the results of prior tests conducted at another reactor site. (4) There, the error introduced by the thermal 1 ag in the temperatures of the contents of the reference volume and pressure vessel had been evaluated for reference volumes down to 2 in. in diameter. From a reference volume, 0.68 in. in diameter and with a thin copper tubing wall 35 mils thick, no measurable error due to thermal lag was expected for at least limited or reasonable changes in the temperature of the air in the containment vesse1. The validity of the Reference Volume Method of testing depends on this design factor.

The proper distribution of a long reference volume throughout the containment vessel also contributes to the validity of the results. For this test, the reference volume tubing was installed in the vessel so that the volume of the tubing and the size of that part of the vessel in which the tubing was located were approximate1y proportiona1. For example, about $71 \%$ of the reference volume was included in the reactor hall which contained about $75 \%$ of the free space in the vesse1. The reference volume was also mounted as closely as possible to the central portion of each section of the vesse1 it served. It was thermally insulated from al1 wall surfaces and mounting straps supporting it.

* Errors resulting from inadequate water vapor pressure measurements are common to both the Absolute Method and Reference Volume Method of leakage rate testing. 
Short sections of high vacuum rubber hose* thermally isolated the reference volume copper tubing from the servomanometer at one end and an oil column and oil recharging mechanism at the other end.

After installation, the entire reference volume was evacuated to $5 \mu$ mercury and then cut off from the pumps and the cold trap.** A maximum allowable leakage limit of $10 \mathrm{\mu} / \mathrm{hr}$ had been established. The observed leakage rate was less than $18 \mathrm{\mu} / 3 \mathrm{hr}$, with most of this occurring immediately after isolating the pumps. This was attributed mostly to outgassing, as no special treatment was given to the copper tubing or the soldered joints.

The coupling between the reference volume tubing and the manometer cistern was leak checked by pressurizing the reference volume and the manometer to 3 psig with helium and air. Leak checking was performed with a mass spectrometer type leak detector. Operating on its most sensitive range, the leak detector will respond to a leak of about $10^{-8} \mathrm{~cm}^{3} / \mathrm{min}$. No 1 eaks were detected at the coupling or at the cistern of the servomanometer when checked in this manner. (See item 4 on page 8) On one occasion between tests, the reference volume was inadvertently moved, creating a leak at a joint which was detected on the following test. The reference volume was repaired and rechecked completely as above.

Remote operation of equalization of the manometer was necessary because all of the reference volume and the manometer

\footnotetext{
* Surgical Tubing-Rubber, Amber Pressure and Vacuum Grade A, $1 / 2$ in. ID, $1 / 4$ in. thick wa11s.

* One end of the reference volume was coupled directly to the pumps and the other provided with a temporary seal for this test.
} 
were included within the contained volume. Equalization was accomplished by extending one end of the reference volume into a 36 in. long column of manometer oil. Draining the oil column with a remotely controlled solenoid valve vented the end of the reference volume to the vessel atmosphere during pressurization; thus, equalizing the reference volume to the containment vessel. An oil reservoir with a second remotely controlled solenoid valve provided more than one cycle of operation. This design eliminated the need for an equalization valve with absolute shut-off characteristics.

The other end of the reference volume was coupled to the lid of the cistern of the servomanometer, as noted earlier. The precision bore tubing of the manometer was immersed in the oil in the cistern at one end and vented to vessel atmosphere at its top.

\section{Vesse1 Pressure}

Vessel pressure was determined by summing results from a precision pressure gage and a barometric pressure gage mounted side by side, both equipped with mirrored rings, and referenced to the same pressure. The pressure gage was connected directly to the containment wall using a spare penetration flange. It was accurate to the nearest 0.25 in. water. The barometric pressure was read to the nearest $0.2 \mathrm{mbar}$, which is approximately 0.1 in. water pressure. Hence, the absolute vessel pressure was measured to about the nearest 0.4 in. water pressure.

\section{Differential Pressure}

The differential pressure that developed between the containment vessel volume and the reference column was determined with installed process instrumentation, a servomanometer which 
is normally used to monitor the level of the heavy water moderator in the reactor. The device is essentially a cistern manometer with a float in a precision-bore manometer tube. As the vessel pressure decreased due to leakage, the oil level rose in the precision bore tubing, carrying the float. A linear differential transformer coil and servo system followed a small iron slug extending from the float. Electrical readout was transmitted to the control room. The resolution of the instrument is 0.002 in. water. During the test, an oil with an extremely low vapor pressure and a specific gravity of 1.00 was used to avoid the need to consider corrections for changes in vapor pressure within the reference volume.

\section{Vapor Pressure}

Vapor pressure was determined by measuring the dew point of the contained air with two transducers, which essentially were resistance temperature detectors. Their resistance had almost a linear relationship with the dew point temperature of their environment as given by a factory supplied table relating dew point temperature to ohmic resistance of the device. Using the steam tables, a direct relationship of vapor pressure in in. water to ohmic resistance of the dew cell was prepared.

The resistance of the dew cell was determined with a five place bridge using an electronic galvanometer to detect the null balance. Vapor pressure measurements to the nearest 0.025 in. water were easily available, but vapor pressure was reported only to the nearest 0.1 in.

The two dew cells were checked in the shop over a two weeks interval prior to the test to determine their response to identical environments. During this test a $0.3 \Omega(0.75$ in. water pressure) difference was noted between cells, and after installation, an additional $0.5 \Omega$ was measured in the resistance of 
the cells due to differences of the lead lengths. The overall correction was $0.8 \Omega(0.2$ in. water pressure), which was used to correct the appropriate dew cell measurement during the tests. In the test, one dew cell was located in the approximate center of the large reactor hall of the containment vesse1; and the second was located in the process cell, about $20 \mathrm{ft}$ above the floor level, and above a sump area.

The resistance winding of the dew cells was directly exposed to the environment, as the protective draft covers(shields for the windings) were not used. The extensive circulation of the air in all parts of the vessel throughout the tests helped to obtain a representative response from these units. Some fluctuations in dew point readings resulted from changing air currents in the vessel which affected the dew cells at the resolution which was attempted. Vapor pressure results for use in estimating leakage rates were determined by graphically averaging the results, which reduced the precision that was attempted with this measurement.

In subsequent tests where vapor pressure is to be measured with accuracy, it would be better to install the dew cells in temporary ducts 6 to 8 in. wide located in the center of the vesse1. Air would be drawn through the duct with a low flow coaxial fan located at the exit of the duct. Two things would be accomplished: namely, assurance of a representative sampling of the vesse1 air by supplying the duct with proper extension ducts; and accurate vapor pressure measurements from the high resolution possible from stable readings, unaffected by changing air currents in the vessel.

6. Vesse1 Temperature

Temperatures were determined from six thermocouples, five of which were tightly clamped onto the copper tubing reference 
volume at appropriate locations along its length. Three of the five thermocouples were located in the reactor hall.

A single thermocouple was centrally positioned in each of the two large cells into which the reference line extended. All thermocouple junctions were forced into intimate contact with the copper tubing and were insulated from surface drafts.

Temperatures that were representative of the contents of both the reference volume and the containment vessel could be determined with the same measurement, because of the thin wall of the reference volume, of the location of both the reference volume and the thermocouples along the reference volume, and of the extensive recirculation of the air in the vessel during the tests. The sixth thermocouple was mounted on a short, open section of $3 / 4$ in. copper tubing and was located in one of the smaller cells of the containment vessel into which the reference volume did not extend.

An ice bath reference junction, a Leeds and Northrup Type K-3 potentiometer, and an electronic galvanometer for null balance detection completed the setup. Each temperature measurement during the test was recorded to the nearest $0.1 \mu \mathrm{v}\left(\approx 0.003^{\circ} \mathrm{F}\right)$. The corresponding temperatures were determined to the nearest $0.1{ }^{\circ} \mathrm{F}$.

Two checks were given to the thermocouples. Prior to the test, a preliminary check at room temperature was conducted for a week during which time hourly readings were recorded. The equipment used with the thermocouples-the K-3 potentiometer, the standard ce11, and the electronic galvanometer-were similarly checked out and their operation made familiar to those who eventua11y recorded the data. During these checks, it was noted that the standard cell required a thermally insulated box and that a switch to be used for selecting a thermocouple for readout 
contributed an error signal. The switch was abandoned, and for the test, each pair of thermocouple wires was individually connected to the potentiometer for each measurement.

Immediately following the tests, the thermocouples were removed from the reference volume tubing and were given a single point calibration at $29.4 \pm .01{ }^{\circ} \mathrm{C}\left(84.9{ }^{\circ} \mathrm{F}\right)$, which was a typical temperature obtained in the vessel during the test. A precision controlled temperature bath, held at this temperature for $4 \mathrm{hr}$, provided the calibration. Data were taken each half hour. In the subsequent analyses, each thermocouple reading was corrected from these test results as tabulated below in Table $I$.

TABLE I

THERMOCOUPLE CALIBRATION

K-3 Potentiometer Temp. ${ }^{\circ} \mathrm{F}$ Deviation ${ }^{\circ} \mathrm{F}$

\begin{tabular}{|c|c|c|c|}
\hline Thermocouple & millivolts (average) & (average) & (to be added) \\
\hline 1 & 1.4752 & 83.9 & +1.0 \\
\hline 2 & 1.4493 & 83.0 & +1.9 \\
\hline 3 & 1.4640 & 83.5 & +1.4 \\
\hline 4 & 1.4654 & 83.6 & +1.3 \\
\hline 5 & 1.4810 & 84.1 & +0.8 \\
\hline 6 & 1.4579 & 83.3 & +1.6 \\
\hline
\end{tabular}

Considering the design, the installation, and the precision of the equipment, the measurements provided a reasonable estimate of the temperature of the vessel air, sufficient for the reference method of testing. As noted above, the high rate of recirculation of the air in the vessel assisted in adding to the acceptance of the temperature measurements. 


\section{PROCEDURES}

\section{Pressurization}

The vessel was pressurized using two large compressors, one of $600 \mathrm{scfm}$ and the other of 360 scfm capacity, each equipped with an oil separator and both discharging into a 2 in. line entering the vessel at a penetration normally occupied by a vacuum breaker. A tee and spool piece provided an entry point and still retained the vacuum breaker. An additional oil filter was installed in the 2 in. line to assist in removing oil. The rate of pressurization was about $1.8 \mathrm{psi} / \mathrm{hr}$, e.g., in the final test pressurization proceeded uniformly to 15 psig in about $81 / 3$ hours.

\section{Vesse1 Ventilation}

To attain as uniform conditions of temperature and humidity as possible within the vessel, all doors were opened and cell covers were removed so that the containment vessel interior would approximate one large hall. In addition, the nine recirculating ventilation blowers in the containment vessel were operated continously during the tests. The air input to each was reduced up to $75 \%$ to avoid their overloading with the denser air at 15 psi of overpressure. The capacities of these blowers varied to match the heat loads in the various locations. Two blowers were located in the reactor hall (about $300,000 \mathrm{ft}^{3}$ or $75 \%$ of the free space), with each blower recirculating about 12,000 scfm under normal conditions and almost that amount under the test conditions. The process cell (about one fifth the free space) had very nearly the same recirculating capacity to handle the large heat sources present during normal reactor operation. To assure complete movement of air in the vesse1, two Coppus blowers (capacity of $1500 \mathrm{scfm}$ ) were located in the bottom of 
the containment vesse1 (-32 ft leve1). One blower was located in the process cell and the other in the experimental cell. A plastic sock, approximately $12 \mathrm{in.}$ in diameter and $80 \mathrm{ft}$ long, was placed on each blower and directed the air from the lowest level directly up into the reactor hall to within $30 \mathrm{ft}$ of the top of the dome. In this manner the containment vessel air was continously and thoroughly mixed.

\section{Moisture Contro1}

Considerable effort was made to provide conditions conducive to stable dew point temperatures while the vessel was pressurized.

The compressors were equipped with oil and water separators. These units are normally used as portable fresh air sources for work requiring $100 \%$ respiratory protection (ful1 face protection and breathing air). The oil and water vapor content of the compressed discharge of these units is much less than that of the conventional air compressor.

Schedules for pressurization were dependent on factors other than optimum weather conditions. However, ambient temperatures were fairly stable, and the relative humidity was less than $40 \%$ during periods of pressurization for most tests.

Before each test, the sumps were drained of any water that had accumulated as a result of maintenance work between tests. All water on the floors was removed and the floors were dried. The discharge water pit with a surface of 7 by $161 / 2 \mathrm{ft}$ was not drained. However, the cover blocks of the pit were put into place and a plastic sheet was placed over their tops. All drums of heavy water in the vessel were properly handled as described earlier. Quite stable vapor pressures resulted throughout each test. 


\section{4. $\quad$ Test Conditions}

The constant temperatures that resulted in the vesse 1 throughout the test were due in part to the rather stable ambient conditions that occurred during testing and to the insulation material on the shell. The portion of the PRTR containment vessel above the ground level is equipped with three inches of beaded, polystyrene foam insulation. The effect of the vesse1 insulation in reducing temperature fluctuations within the vesse1 is shown directly in Figure 1.

Also in Figure 1, ambient air temperature, vessel air temperature, and vessel vapor pressure are compared during a test conducted over a $23 / 4$ day period. The relative humidity of the outside atmosphere during periods of pressurization is shown. The pressurization to 15 psig from 5 psig was started at an outside humidity peak resulting from a brief thunder shower. However, the rate of gain in moisture content in the vessel at this time was no greater than that which occurred earlier during the pressurization to 5 psig while the outdoor relative humidity conditions were more stable. Significant to the analyses of the tests is the comparison between the ambient temperatures, which changed by as much as $37^{\circ} \mathrm{F}\left(40^{\circ} \mathrm{F}\right.$ to $\left.77^{\circ} \mathrm{F}\right)$, and the average vesse1 temperature, which varied by less than $2{ }^{\circ} \mathrm{F}$ during the same period. This was typical of all tests.

The vapor pressures in the vessel during this period remained essentially constant, varying about 0.35 in. water above and below an average value.

During the test for which data are shown in Figure 1 , leakage rate tests at 6 and 15 psig and a superimposed leakage rate test were completed. During all tests, the vessel temperatures (and vapor pressures in some cases) were plotted as the information was accumulated, as shown in this figure. 


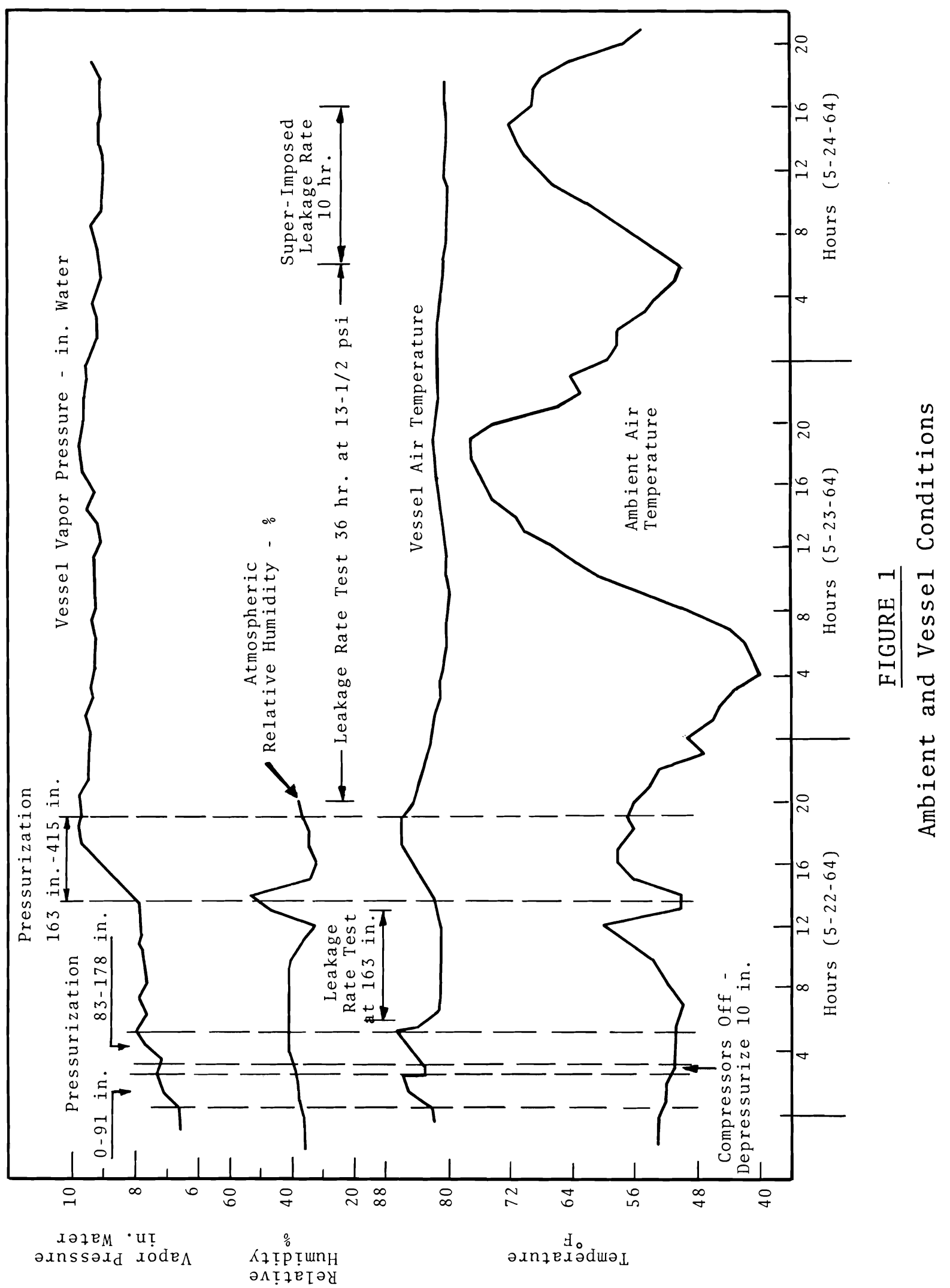


Because of (a) the extremely low variation in temperatures in the vessel during the test periods, (b) the extensive recirculation of air in the vessel, and (c) the layout and the thin walls of the reference volume, the temperatures of the reference volume and vessel were assumed to be equal to each other throughout the tests. This suggests that any interval of time for measuring leakage rates is as suitable as any other, and that it is not necessary to test for $24 \mathrm{hr}$ or to complete the diurnal cycle in order to be able to compare results obtained under similar conditions.

5. Data Handling

The following data were taken at half hour intervals dureach test:

- Vessel gage pressure

- Barometric pressure

- Vapor pressure*

- Differential pressure

- Six temperatures

The data from the test instruments, all of which were located at one position in the reactor control room, were logged on prepared formats. During the first leakage rate test, conducted at 6 psig, it became apparent that the precision servomanometer measuring the differential pressure between the vessel and reference volume had sufficient resolution to provide an almost immediate estimate of the existing leakage rate, as described below. This reading was recorded first at 1 min intervals, and subsequently at 5 min intervals.

Where the precision warranted some data were recorded to the fourth significant figure, e.g., absolute pressure at 801.7 in. water. All computations of leakage rate were made with a

"Taken during the pressurization periods also. 
desk calculator and entered on prepared formats as soon as the data were taken and were recorded routinely to the fifth significant figure.

The relationship used to determine the leakage rate was:

$\because 1$ eakage/24hr $=100\left(\frac{24}{\mathrm{H}}\right)\left[1-\frac{\mathrm{P}_{2}-\left(\mathrm{P}_{\mathrm{v} 2}-\mathrm{P}_{\mathrm{v} 1}\right)}{\mathrm{P}_{1}} \times \frac{\mathrm{P}_{1}+\Delta \mathrm{P}_{1}}{\mathrm{P}_{2}+\Delta \mathrm{P}_{2}}\right]$

The development of this expression is given in Appendix III.

Temperatures were measured, and the results were plotted as the vessel was pressurized (Figure 1). When the temperatures and vapor pressures from these plots appeared to be fairly stable, the test data accumulated thereafter were used to determine the leakage rate.

LOCAL LEAK DETECTION METHODS

Three local leak detection methods were employed during the tests. They were soap bubbles, volume displacement, and ultrasonic leak detector. Of the three, the soap bubble technique was generally the most useful. The soap bubble solution was particularly useful around mechanical seals such as airlock doors and around electrical conductors which were imbedded in the epoxy potting-compound-filled penetration trays. It was also useful in identifying leakage through electrical conductor sheathing, between insulated conductors, and through the multiconductor bundle insulation. However, it was quite difficult to assess the leakage rate by watching the rate of bubble formation.

Volume displacement was used to evaluate leakage past aqueous containment valves, past the sluice gate seal, and, in some cases, through an insulated electrical conductor. The water level at the terminal point beyond the containment valves was 
established before the test started and was then measured periodically. In leak testing the electrical conductors which could be removed from their terminals outside the containment vesse1, the cable was de-energized and disconnected, and the free end immersed in a bucket of water. By inserting the bubbling end of the cable into a graduated cylinder, the leakage rate could be 'measured quite accurately. A second method was to insert the cable into rubber tubing connected to a portable flowrate meter. This also gave an accurate measure of the leakage rate. Combining this method with the use of soap bubbles permitted reasonably good leakage rate estimates.

The ultrasonic leak detector was used as a quick-scanning device over a large number of wire runs and instrument tubing fittings where the escaping air had some minimum sound frequency detectable with the translator but inaudible to the human ear. The translator was not effective in detecting leaks diffusing through a porous wire insulation such as that found on thermocouple wire. The instrument was moderately directional thus permitting careful scanning in crowded equipment locations.

\section{TEST EXPERIENCE}

Test 1

The containment vessel pressure was raised to 3 psig* as planned. At this pressure, entry was permissible from a safety standpoint, and the vessel was inspected for problems which had not been considered adequately in the planning phase. At 3 psig, a significant leak was discovered on a flanged pipe connection where the recirculating shield coolant piping extends through the vessel wall into an underground vault. The flange bolts were tightened, and the leak stopped. Other leak points were observed, as shown in Table II.

*A1 pressures are nominal values unless otherwise noted. 
TEST 1 RESULTS (Maximum Pressure Obtained-6 psig)

Leaks Observed

1. Between main electrical conductor insulation and potting compound on 3 potted, penetrations $(2,13,32)$.

2. Along porous thermocouple wire insulation and individual insulated wire ( 5 penetrations: $24,25,33,42,43$ )

3. Vulcanized patch on airlock inflatable seal caused pressure leak path.

4. Three screwed fittings on ventilation exhaust duct upstream of containment valve.

5. Seepage leak in general around emergency airlock inflatable seal.

6. Water leve1 in irradiated fuel storage basin inside containment vessel dropped 18 inches in 15 hours.

7. Flange leak where cleanup piping system penetrates vessel.
Repairs Performed

1. Formed penetration extension on inside of vessel and filled with potting material.

2. Same as No. 1 .

3. Replaced entire inflatable seal.

4. Tightened.

5. Scoured seating surfaces.

6. None. Leak rate was $10 \mathrm{cfh}$ at 6 psig.

7. Tightened flange while pressurized.

\section{Observations on Following Test}

1. Penetration 13 leaked slightly.

2. Penetrations 42 and 43 leaked slightly.

3. Leak corrected.

4. Slight leak persisted acceptable.

5. Improved to acceptable leak rate.

6. Remained the same; acceptable.

7. Leak eliminated. 
Before depressurizing, the pressure was increased to 6 psig, and the containment vessel again was entered to inspect a11 deactivated equipment. All conditions were observed to be satisfactory. The estimated leakage rate of the vesse1 was $7.4 \% /$ day at the test pressure.

The leakage rate of $7.4 \%$ was a result in part of the test conditions and was not an indication of the normal operating conditions, the containment vesse 1 is at 0.5 in. water negative pressure, which has never been exceeded in the operating history of PRTR.

A mechanical interlock on the personnel airlock malfunctioned while one person was in the vesse1 at 6 psig pressure, and a two hour effort was required before the interlock functioned properly to permit the employee's exit. Repairs and checkout were completed when the vessel was next depressurized.

Breathing of the vented calandria and reflector into the tightly closed containment vessel with every pressure test cycle caused an unexpected increase of the tritium concentration in the air in the vessel. Personnel who entered the vessel while it was pressurized or immediately following depressurization, received some tritium exposure. Routine bioassay sample results disclosed the condition just prior to the start of the third pressure test. All exposure from the tritium was within administrative limits.

Test 2

The containment vessel pressure was raised to 6 psig. The observed leakage rate was $3.1 \%$ day at the test pressure. Small leaks again were observed on previously repaired electrical conductors, a1though improvement was noted. 
The most significant leak observed was past the boiler flash tank bottoms containment valve, whose line discharges into a sewer outside the vessel. Although the boiler had been filled with water prior to the start of the test, vessel pressure had displaced most of the water permitting a direct air leak path.

After depressurization was complete, the containment valve was disassembled, and a considerable amount of boiler sludge was found blocking the valve open. Other observations and repairs are noted in Table III.

Test 3

The containment vessel pressure was raised first to 5.5 psig, then later to $15 \mathrm{psig.} \mathrm{At} \mathrm{the} \mathrm{former} \mathrm{pressure,} \mathrm{the} \mathrm{observed} \mathrm{leak-}$ age rate was $5.2 \% /$ day. Difficulty was encountered in keeping the secondary coolant system filled; the pressurized shield coolant drain line containment valve was determined to be not functioning properly. In addition, the vessel test instrumentation became unreliable. No leakage rate evaluation was made, but inspection for leaks continued. It became apparent during this test attempt that novel local leak detection methods would be required to pinpoint leak locations. Particular emphasis was placed on all piping and electrical conductors leaving the vessel.

On this first test at 15 psig, the airlock mechanical seals, the ventilation containment valves (two, 26 in. diam. butterfly valves), and the vacuum breakers were found to be virtually leak free; and no repair effort was necessary. The leakage rate past these six mechanical closures was estimated to be less than $250 \mathrm{scf} / \mathrm{day}$. Observations for this test are noted in Table IV. Test 4

The vessel was pressurized to 6 psig. Repairs to penetration 10 were not successful, as the intermittent leak through 


\section{$\underline{\text { TAB LE II I }}$}

\section{TEST 2 RESULTS (Maximum Pressure Obtained-6 psig)}

\section{Leaks Observed}

1. Flash tank bottoms discharge line containment valve blocked open by sludge.

2. Leak along instrument air tubing (penetration 6)

3. Between main electrical conductor insulation and potting compound (penetrations 13, 26).

4. Along porous thermocouple wire insulation and other miscellaneous individual electrical conductors (penetrations $17,27,30$, $42,43)$.

5. Boiler relief line containment valve.

6. Instrument air lines from containment vessel to contro1 room.

\section{Repairs Performed}

1. Disassembled valve and cleaned out sludge.

2. Tightened rubber grommet where sheath leaves penetration.

3. Made special cup around electrical leads and poured new potting compound.

4. Potted individual wires at first junction box in containment vesse 1 .

5. Reseated valve several times.

6. Closed isolation valve, capped spare lines, tightened fittings.
Observations on Following Test

1. Did not leak.

2. Slight leak persisted.

3. Leak still present, but reduced in rate.

4. Moderate reduction in leak rate from previous observation.

5. Sma11 acceptable leak.

6. Corrected a11

leaks observed. 


\section{TABLE IV}

\section{TEST 3 RESULTS (Maximum Pressure Obtained-14.8 psig)}

Leaks Observed

1. Leak along instrument air tubing (penetrations 6 and 10).

2. Significant leak through potted penetration 10 .

3. Temporary pressure test wire run through spare penetration leaked.

4. Many main electrical conductor leads leaked at

first terminal connection outside containment vessel. Most multi-conductor cables leaked at the terminal end. Leaks were observed channeling along bare wire, through insulating material or along multistrand wire conductors.

5. Containment check valve on Rupture Loop drain return ine would not seal properly.

6. Miscellaneous instrument air line fittings.

7. Process water supply containment check valve.

8. Leaks through porous electrical lead insulation or along insulated wire (penetrations $13,17,25,27$ $29,42,43)$.

\section{Repairs Performed}

1. Split bundle sheathing on vessel side and filled sheath with potting compound.

2. Made small potting pour across top of penetration opening, vessel side.

3. Formed potting vessel and sealed penetration.

4. Main conductor leads insulation was split just inside vessel, potting compound forced in and around bare wires and allowed to set up. Insulation taped back in place. All other electrical leads were potted at the first break in their insulation. Normally, this was at distribution junction boxes.

5. Removed check valve, installed blank to permit further testing and to permit bench testing of valve.

6. Tightened.

7. Reservoir filled to provide water seal across valve.

8. Added potting compound to penetrations on vessel side.
Observations on Following Test

1. Significant reduction in leak rate.

2. Intermittent leak persisted. Original potting never hardened, and vessel pressure channeled air leak through the compound.

3. No leak.

4. Considerable improvement was made on significant leakers. Some individual leaks were not repaired due to type of conductor (porous insulation, etc.).

5. Valve was worked over and bench tested satisfactorily.

6. No leaks.

7. No leaks.

8. Leak rate decreased, but still present on most penetrations. 
the potting compound persisted. Significant improvement was realized on the leakage rate through the electrical conductors, but a few were leaking badly enough to require additional sealing

On one electrical lead, it was determined that a break in the insulation existed in the conduit at a point between where the conductor insulation was slit and potted and where the conductor passed through the vessel penetration. Potting at another point reduced this leak. The leakage rate was observed to be $1.4 \% /$ day at this test pressure. Test observations are noted in Table V.

Test 5

The vesse1 was pressurized to $15 \mathrm{psig}$, and a $36 \mathrm{hr}$ leakage rate test followed by a $10 \mathrm{hr}$ superimposed leakage rate test was conducted. The leakage rate was determined to be $1.3 \% /$ day, and the superimposed leakage rate was an additional $0.9 \%$.

It was apparent during this test that penetration 10 containing the soft potting compound, could not be repaired properly by the techniques used. This penetration contained 8 bundles of 10 each plastic instrument air tubing runs; and inasmuch as only 5 lines were actually needed to operate the rupture 1oop, the decision was made to abandon the penetration for the present. A11 instrument air lines were cut at the penetration, and a $1 / 4$ in. thick plate was cemented to the smooth face of the penetration tray using a steel-epoxy plastic mix. The plate was then bolted to the tray. The top opening of the penetration tray was sealed in a similar manner with the plate held fast by a backing channel iron and two holddown bolts. The leak was stopped after this effort.

Other significant leaks were identified and corrective effort undertaken as noted in Table VI. 


\section{TABLE V}

TEST 4 RESULTS (Maximum Pressure Obtained-6 psig)

Leaks Observed

1. Penetration No. 10 leaked through soft potting compound.

2. Gas loop heater lead leaked through at terminal.

3. Three multi-conductor bundles leaked through to junction box (from penetration 41).

4. Individual communication wire runs and shim rod wire runs leaked at terminal end.

5. Leaks along electrical conductors where they were sealed through the penetrations $(13,27,3)$.

6. Leaks through individual wire runs were still evident, but generally much improved over status of Test 3 .

\section{Repairs Performed}

1. Poured potting compound into crevices, split instrument air tubing bundles, and filled with potting compound.

2. Slit conductor insulation at point near vessel exit point and poured potting compound.

3. Outer insulation was slit in vesse1, and potting compound poured around individual conductors.

4. Individual potting poured at first junction box in containment vesse1.

5. Made another attempt to seal existing potting on pressure side of vessel.

6. Miscellaneous additional effort on the more significant leak points by additional potting at first junction box in vesse1.
Observations on Following Test

1. Leak corrected initially, but intermittent leak developed after about $4 \mathrm{hr}$ at 15 psig.

2. Some improvement, but leak persisted.

3. Leaks corrected.

4. Improvement made; some leakage still existed.

5. Improvement made. Penetration 27 remained the worst.

6. Further improvement made. 
TABLE VI

TEST 5 RESULTS (Maximum Pressure Obtained-15 psig)

Leaks Observed

1. Leakage of penetration 10 genera11y worse.

2. Leakage along individual wire runs (penetrations $2,3,27)$.

3. Gas 1oop heater C lead phase $1 \mathrm{~A}$ leaked at saturable reactor termina 1 .

4. Shim rod wire runs leaked at terminals outside vesse1.

5. Several instrument air line leaks at fittings behind control room pane1s.

6. Several individual wire runs leaked more than average.
Observations on Fo11owing Test

1. Abandoned the penetration and sealed.

2. Additional potting compound poured over all earlier pours.

3. Same as No. 2

4. Nothing.

5. Fittings either tightened or replaced.

6. Additional potting at first junction box in vesse 1 .
1. Leak eliminated

2. No measurab1e improvement.

3. Very sma11 leak.

4. Same as before.

5. Leaks eliminated.

6. Improvement acceptable. 
FINAL TEST RESULTS

A final test was made at 14.3 psig. The repair effort after Test 5 was believed to be sufficient to achieve an acceptable leakage rate. The same leak inspection was made as previously, however, to record the known leaks and to make repairs on those leak points which could be corrected. In many instances on the electrical wiring, at least three attempts had been made to eliminate the leak. In the more significant leak cases, the leakage rate was reduced considerably as shown in Table VII.

\section{$\underline{\text { TABLE VII }}$}

FINAL TEST RESULTS (Average Pressure Obtained-14.3 psig)

Leaks Observed

1. Both vessel vacuum relief valves

2. Sluice gate

3. Penetration 27

4. Penetration $2,3,25,31,42,43$

5. Wire runs to compressors, rupture loop heater, shim rod cables, gas loop heater

6. Primary pump electrical power leads (15 tota1)

7. Majority of multi-conductor wire runs terminating behind control room panels

8. Ventilation containment valves

9. Airlocks and equipment access door

10. Effluent containment valves

11. Wire runs to junction box RL JBX
Estimated Leakage Rate, scf/day

50
500
200
600

1000 Total
100
Unknown,
individuaily
serya11
50
150
0
100

Very little improvement of minor leaks was realized, mainly because of the porosity of the wiring insulation and probable breaks in 
the insulation. The test was performed over a $12 \mathrm{hr}$ period with a measured leak rate of slightly less than $0.9 \pm 0.1 \% / 24 \mathrm{hr}$ when extrapolated to 15 psig.

COMMENTS ON TESTING

The time and repair efforts required to achieve an acceptable leakage rate were considerably more than anticipated. The difficulties encountered with the aqueous containment valves were not foreseen in advance, and the magnitude of the leakage through the many electrical wire runs was greatly underestimated. The large openings into the containment vessel were, in general, more leak tight than was expected.

The leakage rate for the PRTR containment vesse1 is expected to remain adequately low, since all the leaks repaired were permanently sealed. Further improvement over the present status is planned on a long range basis, by replacing the present method of penetration* with improved designs.

Several important points were learned as a result of this series of tests.

- Testing aqueous containment valves cannot be performed merely by observing mechanical valve action. A means to observe or measure flow past the closed valve is necessary for a meaningful test.

*A11 wire runs were passed through the penetrations with their insulation intact. Potting compound was then poured into the penetration tray, sealing the opening, but not the unbonded area between the conductor and its insulation. The plastic air lines in contrast had their bundle sheathing removed in the penetration tray, and the individual air lines were imbedded in the potting compound. Even this method was not completely successful, as there were four leaks observed where the air lines left the penetration. (See also Figure II-1, Appendix II) . 
- Mechanically sealed penetrations, such as personnel air locks and vessel vacuum breakers, require some preventive maintenance attention on a routine basis to maintain the required leak-tightness.

- Electrical wire runs cannot be sealed properly unless the sealant is in direct contact with the conductor. Wiring with unbonded insulation can never be sealed completely against leakage in any other manner.

- Potting compounds properly mixed and aged before testing do not appear to deteriorate. In the case of penetration 10 , it was shown conclusively that the potting compound did not have the proper mixture of adhesive and hardener. The compound was still quite fluid after 4 years.

\section{ANALYSIS OF THE TEST AND THE RESULTS}

\section{Corrections}

Several considerations were included in the reference volume design and installation which contribute to the acceptance of the results. The configuration, i.e., the small internal diameter (0.68 in.) and the thin copper wall (0.035 in.) of the reference volume, was a direct extension of work reported earlier. With this configuration constant thermal equilibrium between the vessel air and the reference volume could be achieved for reasonable variations in temperature.

In addition, the reference volume was distributed so that different sections of the vessel contained proportional parts of the reference volume. The reference volume functions as an accurate gas thermometer if it is designed to remain in thermal equilibrium with the air in the vessel and if it is laid out to be a volume-averaging device. 
The reference volume must be absolutely leak-tight, which was not too difficult to achieve. Demonstrating the leak tightness proved more difficult because a roughing pump, a diffusion pump and a cold trap were required before it could be shown that the leakage, if any, was essentially zero.

Corrections for the minor changes in the containment vessel volume which might result from pressure or temperature variations during the testing were not considered. However, the small changes in the reference volume occurring with each change in the manometer level created a corresponding change in internal pressure in the reference volume, which was extraneous to the differential pressure being measured.

As developed in Appendix IV, the magnitude of the correction factor (B) expressed in terms of inches of water pressure per each inch of pressure difference measured between the reference volume and the containment vessel was

$$
B=P_{1}(0.0004) \text {, }
$$

Where

$$
\mathrm{P}_{1}=\text { the absolute pressure. }
$$

Hence, for a differential pressure measurement of $\Delta \mathrm{P}$ in.,

$$
\mathrm{B}=\mathrm{P}_{1}(.0004) \Delta \mathrm{P} \text {. }
$$

The corrected differential pressure measurement $\Delta \mathrm{P}_{\mathrm{C}}$ became

$$
\Delta P_{C}=\Delta P+B
$$

or

$$
\Delta \mathrm{P}_{\mathrm{C}}=\left(1+\mathrm{P}_{1}(.0004)\right) \Delta \mathrm{P}
$$

where

$$
\Delta \mathrm{P}=\text { the measured differential pressure. }
$$


When $\mathrm{P}_{1}$-the absolute pressure-was at about $800 \mathrm{in.}$, as it was during a 14.3 psig test, the correction factor became about 0.3 in./in. of $\Delta \mathrm{P}$, or about $30 \%$. This factor was a known correction which could be precisely determined and was essentially eliminated as a factor in the results in the manner of handing the data; $i$. e., the values of $B$ became small parts of two large numbers which formed a quotient. (See Appendix III).

It can be shown that the magnitude of the correction factor is due to (a) the comparatively large bore size (0.75 in.) of the differential manometer tube which accommodated the float; (b) the total volume of the reference volume system; i.e., had the volume been three times as large, the correction factor would have been reduced correspondingly; and (c) the method of equalization between manometer legs which was adopted for this test. While providing the absolute assurance that no leakage path between reference volume and vessel volume would result through an equalization valve, this method of equalization essentially doubled the magnitude of the correction factor B. However large, the correction factor was accepted because it was precisely measured; and when used, it was largely self cancelling.

\section{Expected Error}

Expected errors, if properly estimated, permit a determination of the degree of uncertainty in the results of the tests prior to the testing. Such an analysis is useful largely in determining in advance the resolution and the accuracy required in the instrumentation to be used. If the predicted error or uncertainty approaches the magnitude of the permissible leakage rate, the test results may not be definitive. Often the lowest leakage rate that can be reliably quoted on a containment vesse1 is determined by the errors inherent in the measurements and not by the measurements themselves. 
In this test, the predicted errors and uncertainty were determined in the following manner. Errors can be expected both in the measurements and in instrument accuracy. Measurement errors here are considered to depend mostly upon the installation of the test equipment. For example, the measurement of the temperature of the air in the very large volume of containment vessels is not easily made with certainty. If a measurable change in temperature occurred in about $50 \%$ of the vesse1 air, the detectors should have been located and installed such that about half of those which were used to provide the average temperature would have responded correspondingly. Some error in measurement would result if this were not the case.

Instrument accuracy in these tests is defined as the ability of the equipment to give the same output repeatedly to a high degree of resolution, when exposed to the same source. This must occur over a reasonable span of source values.

Absolute accuracy is not required. For example, a barometric pressure measurement of 975.0 mbars obtained repeatedly when the absolute value of the barometric pressure was 980.3 mbars would be considered quite accurate, regardless of the fixed error of 5.3 mbars. Table VIII lists the expected error in each measurement that was predicted from the instruments used in these leakage rate tests.

The dew cell instrumentation, which measured resistance on a five place bridge, was accurate to better than $0.05^{\circ} \mathrm{F}$ in dew point or .02 in. of water vapor pressure on a relative basis. Considering the method of obtaining an average dew point (vapor pressure) in the vesse1, a precision of $0.1^{\circ} \mathrm{F}$ in dew point temperatures is believed reasonable. 
TABLE VIII

\section{EXPECTED ERRORS IN MEASUREMENT}

(A11 Pressures Given in in. Water)

\begin{tabular}{|c|c|c|c|}
\hline Measurement & Expected Error & & Range \\
\hline Vesse1 Pressure Gage & 0.25 in. & & 415 in. \\
\hline Barometric Pressure & 0.10 in. & & 405 in. \\
\hline Vesse1 Pressure (abs) & 0.4 in. & & 820 in. \\
\hline $\begin{array}{c}\text { Vapor Pressure } \\
\text { or }\end{array}$ & $0.05 \mathrm{in.}$ & & \\
\hline Dew Point & $0.1{ }^{\circ} \mathrm{F}$ & 210 & ${ }^{\circ} \mathrm{F} \quad(127$ \\
\hline Differential Pressure & 0.002 in. & & 120 in. \\
\hline Temperature & $0.1^{\circ} \mathrm{F}$ & & $540^{\circ} \mathrm{R}$ \\
\hline
\end{tabular}

With regard to temperature, the expected error of $0.1{ }^{\circ} \mathrm{R}$ $\left(0.1^{\circ} \mathrm{F}\right)$ is not suggested as the precision available in estimating the temperature of the vessel air. Rather, the error is an indication of (a) the minimal $1 \mathrm{ag}$ in temperature correspondence between the reference volume and the pressure vessel under the best conditions and (b) the ability of the equipment to reproduce estimates of the relative temperatures of both volumes.

*The $127^{\circ} \mathrm{F}$ in range of dew points was estimated only for purposes of error analysis. It was arrived at in this way. The quoted range of the dew cells that were used extended from $-50{ }^{\circ} \mathrm{F}$ to $+160^{\circ} \mathrm{F}$, or a span of about $210^{\circ} \mathrm{F}$. However, reliable and reproducible measurements of dew point at $32^{\circ} \mathrm{F}$ and below are difficult to obtain. Hence, it was assumed that the span of the device was about $127^{\circ} \mathrm{F}$, starting at $33^{\circ} \mathrm{F}$. Two dew cells were used to estimate the dew point (vapor pressure) in the containment vessel. A volume weighted average was computed where the dew point reading from the reactor hall was multiplied by 3 and averaged with the dew point reading of the process cell, since the reactor hall contains about $75 \%$ of the free volume of the vessel. 
The values in the above tabulation can be handled in several ways to predict the measure of uncertainty. One such technique ${ }^{(4,5)}$ utilizes the error propagation 1 aw, which for the reference volume method, can be expressed as

$$
e_{L}= \pm \frac{1}{\Delta t} \sqrt{2\left(\frac{e_{T}}{T}\right)^{2}+2\left(\frac{e_{X}}{x}\right)^{2}+2\left(\frac{e_{P}}{P}\right)^{2}} \times 100 \text {, }
$$

where

$$
\begin{aligned}
\mathrm{e}_{\mathrm{L}} & =\text { uncertainty in the measurement in percent } \\
\Delta t & =\text { time base } \\
\mathrm{e}_{\mathrm{T}} & =\text { error in temperature } \\
\mathrm{e}_{\mathrm{X}} & =\text { error in vapor pressure } \\
\mathrm{e}_{\mathrm{P}} & =\text { error in pressure } \\
\mathrm{T} & =\text { absolute temperature } \\
\mathrm{X} & =\text { vapor pressure (magnitude of span) } \\
\mathrm{P} & =\text { absolute pressure. }
\end{aligned}
$$

The above expression has been changed from that given in the reference to the extent that the factor modifying the temperature error term under the radical is 2 and not 4 as suggester? in the reference. This results from the method of simultaneously monitoring both the reference volume temperature and the vessel temperature in this test, which halves the number of temperature measurements required.

A temperature correction factor is included in the error analyses, although temperatures are not used in the computation of the leakage rate. The term involving temperatures in this expression (see Appendix III), 


$$
\frac{\mathrm{T}_{1}}{\mathrm{~T}_{1}^{\prime}} \times \frac{\mathrm{T}_{2}^{\prime}}{\mathrm{T}_{2}},
$$

was assumed to be unity. To the extent that this is not true, some temperature correction is required.

Using the error propagation law, the predicted uncertainty of the results $e_{L}$ (before the test was started) was $\pm 0.1 \%$ if vapor pressure errors were not included, $\pm 0.14 \%$ if vapor pressure errors were included considering a $210^{\circ} \mathrm{F}$ span in this instrumentation, and $\pm 0.18 \%$ if vapor pressures were included using only a $127^{\circ} \mathrm{F}$ span. The largest contributing factor to the uncertainty was the apparent lack in resolution of the vapor pressure measurement $\left(e_{X}\right)$. Assuming that a reliable leakage rate could be estimated without considering vapor pressure measurments, the predicted uncertainty in the result would be decreased significantly.

The predicted uncertainty, as determined above, is the minimum that can be related to test results. To this must be added the other type of errors that normally accumulate in the routine, manual acquisition of data and can be attributed mostly to human errors. To properly evaluate these, an appropriate statistical analysis on the accumulated data should be performed. This analysis provides the best estimate of the uncertainty associated with the measured leakage rate. If properly handled, it would include all the sources of error noted above. In the results which are given below, the error when not included can be assumed to be at least $\pm 0.1 \%$.

\section{Extrapolating Leakage Rates}

During three of the preliminary tests, leakage rates on the vessel were obtained at two different test pressures, from 
which methods for extrapolating leakage rates between pressures could be examined.

The rules of proportionality considered applicable were:

- $\left(\mathrm{P}_{2} / \mathrm{P}_{1}\right)^{1 / 2}$ for flow (escape) from orifices which is proportional to the ratio of gage pressures to the half power

- $\left(\mathrm{P}_{2} / \mathrm{P}_{1}\right)^{1 / 1.8}$ for turbulent flow proportional to the ratio of the gage pressures to the 0.55 power

- $\mathrm{P}_{2} / \mathrm{P}_{1}$ for viscous flow in capillaries which is linearly proportional to the ratio of the gage pressures.

Table IX compares the results of applying the first two proportionality rules given above. Extrapolating by the ratio of gage pressures raised to both 0.50 and 0.55 power are comparable. The 0.50 power extrapolation is applicable in a11 cases, and a straight linear extrapolation is not applicable at a11.

For example, on May 12 and 13, two leakage rate tests were completed at gage pressures of 157 and 393.6 in. water. At $157 \mathrm{in}$. the leakage rate, determined over an $8 \mathrm{hr}$ period and extended to a leakage rate for $24 \mathrm{hr}$, was $3.2 \%$. When extrapolated to a leakage rate at a pressure of 393.6 in. by the ratio of the gage pressures to the 0.50 power, the leakage rate was $5.1 \%$. Extrapolating the same ratio to the 0.55 power it was $5.4 \%$. The actual leakage rate measurement at 393.6 in. over a $4 \mathrm{hr}$ test was $5.35 \% / 24 \mathrm{hr}$.

As noted, all leakage rates were normalized to $24 \mathrm{hr}$ periods even though the actual test periods varied considerably. For precise determinations of proper extrapolation factors, leakage rate tests at different pressures should be conducted and compared over similar intervals when possible. 


\begin{tabular}{|c|c|c|c|c|c|c|}
\hline \multirow[b]{2}{*}{$\begin{array}{l}\text { Date } \\
\text { in } \\
\text { May } \\
1964\end{array}$} & \multirow[b]{2}{*}{$\begin{array}{l}\text { Test } \\
\text { Dura- } \\
\text { tion, } \\
\text { hr. }\end{array}$} & \multirow[b]{2}{*}{$\begin{array}{l}\text { Test } \\
\text { Average } \\
\text { Pressure, } \\
\text { in. } \mathrm{H}_{2} \mathrm{O}\end{array}$} & \multicolumn{4}{|c|}{ Leakage Rate in $\% / 24 \mathrm{hr}$. } \\
\hline & & & $\begin{array}{l}\text { Measured } \\
\text { at } \mathrm{P}_{1} \\
\mathrm{~L}_{1}\end{array}$ & $\begin{array}{l}\text { As Extrapo- } \\
\text { lated to } \mathrm{P}_{2} \\
\text { by Multiplying } \\
\mathrm{L}_{1} \text { by } \sqrt{\frac{\mathrm{P}_{2}}{\mathrm{P}_{1}}} \\
\end{array}$ & $\begin{array}{r}\text { As Extrapo- } \\
\text { lated to } \mathrm{P}_{2} \\
\text { by multiplying } \\
\mathrm{L}_{1} \text { by }\left(\frac{\mathrm{P}_{2}}{\mathrm{P}_{1}}\right) 1 / 1.8\end{array}$ & $\begin{array}{c}\text { Measured } \\
\text { at } \mathrm{P}_{2} \\
\mathrm{~L}_{2}\end{array}$ \\
\hline 12 & 8 & 157 & 3.2 & 5.1 & 5.4 & \\
\hline 13 & 4 & 393.6 & & & & 5.35 \\
\hline 19 & 1 & 82 & 1.1 & 1.6 & 1.68 & \\
\hline 19 & 3 & 168.2 & & & & 1.63 \\
\hline 22 & 4 & 164.7 & 1.2 & 1.8 & 2.4 & \\
\hline & 16 & 392.9 & & & & 1.4 \\
\hline
\end{tabular}

Another source suggests how to include the contribution from capillary leaks with a linear extrapolation to the overall leakage rate. $(7,8)$ Such information is not entirely academic, if reliable, for it can direct the local leak detection effort. The expression proposed is

$$
\text { leakage rate }=a(P)+b(P)^{1 / 2} \text {, }
$$

with the constants a and b determined by measurement. This empirical equation lumps turbulent flow in channels with orifice flow, which should not introduce much error over the range of pressures considered here.

For the test on May 12 and 13 in Table IX, with gage pressures expressed in inches of water and leakage rate per $24 \mathrm{hr}$ in percent of the contained volume of the building, the constants 
are

$$
\begin{aligned}
& a=1.94 \times 10^{-3} \\
& b=.232 .
\end{aligned}
$$

These constants would indicate that at the higher test pressure (393.6 in. water) about $14 \%$ of the leakage is through capillary channels and $86 \%$ through orifices, which is plausible.

4. Checking the Method

The method of measuring the leakage rate was tested by superimposing a measured leakage rate on the containment vessel for the last 10 hr of one of the preliminary tests. The superimposed leakage rate was measured with a calibrated rotameter which monitored the flowing from a fixed orifice established with a valve and $3 / 8$ in. copper tubing at a spare 2 in. vessel penetration. The leakage rate computed for the $10 \mathrm{hr}$ immediately prior to the test is compared to that for the $10 \mathrm{hr}$ in which the known leak was added as follows:

Leakage rate for the preceding $10 \mathrm{hr}$, 8:00 p.m. on 5-23-64 to 6:00 a.m. on 5-24-64 $1.3 \%$ determined by the equation developed in Appendix II I

Leakage rate for $10 \mathrm{hr}$ from 6:00 a.m. to $4: 00$ p.m. on 5-24-64

Difference, due to superimposed leakage rate $0.8 \%$

During the latter $10 \mathrm{hr}$, the measured flow rate was recorded each half hour using a calibrated rotameter, and the results are shown in Figure 2 .

Each half hour the leakage rate was computed using the ratio of the measured leakage rate to the corresponding contained volume as determined by the vessel pressure. For example, at 12:00 noon the leakage rate was $6523 \mathrm{scfd}$, and the contained 
BNWL- 109

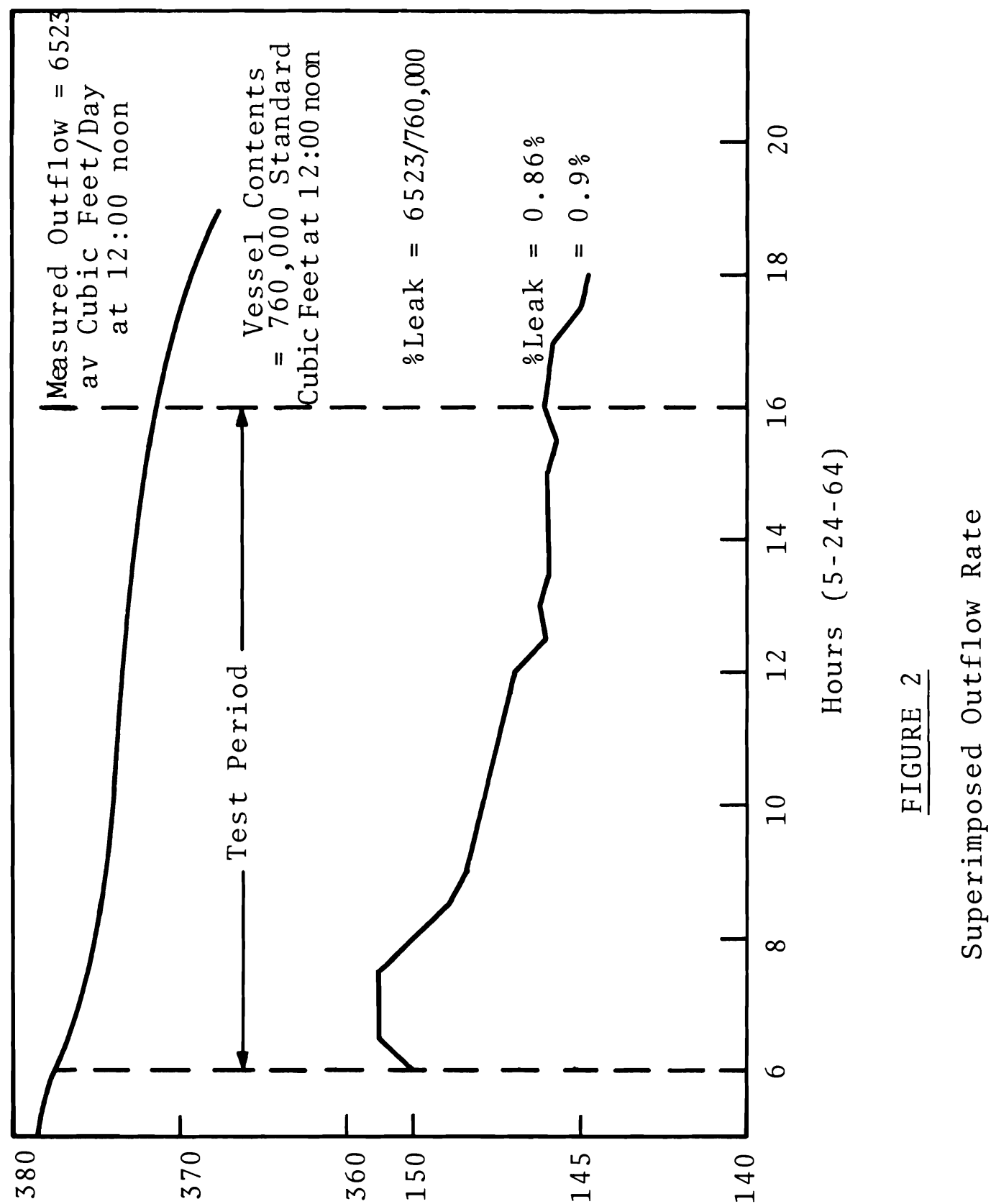

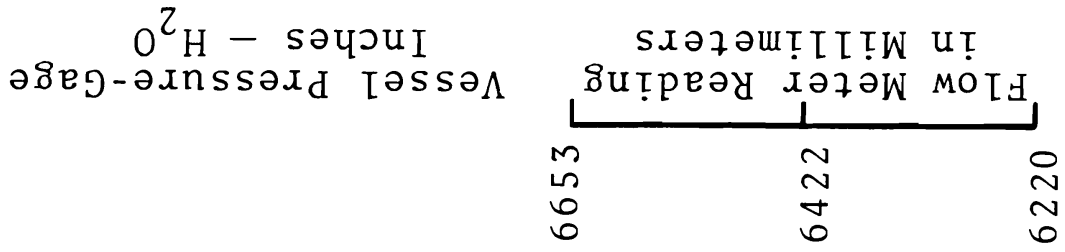

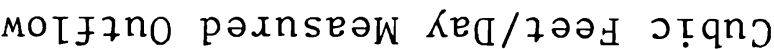


volume at that moment was $760,000 \mathrm{scf}$; from these a leakage rate of $0.86 \% /$ day was determined. The average of 21 measurements, taken at half hour intervals, was $0.864 \% \pm 0.007 \%$ at $95 \%$ confidence limit. The correspondence of results provided assurance in the method and in the installed equipment used in these tests. Conditions within the vesse1 during the test were quite stable, as indicated earlier in Figure 1.

5. Comparison of Test Methods

The Absolute Method, an alternate method of leakage rate testing, requires that accurate and representative temperature measurements be made simultaneously of the vessel contents and of the vessel absolute pressure. A reference volume and measurements of the differential pressure are not required. Although believed to be representative and accurate, the temperature monitors installed for this test were intended primarily to indicate when equilibrium temperature conditions existed in the vesse1. If the Absolute Method of testing had been selected, sufficient additional temperature sensors would have been installed to eliminate any doubt about obtaining representative temperatures.

A comparison of the two methods of determining the leakage rate is given in Table $x$. The average vessel temperature was evaluated from the five thermocouples clamped to the reference volume plus a sixth clamped to a short section of similar copper tubing. No weighting factors were used as three of the six thermocouples were well distributed in the reactor hal1 and the other three were centrally located in each of the three cells below grade leve1. Each of the cells was open to the reactor ha11 and to each other, as described above. 
TABLE X

COMPARISON OF LEAKAGE RATE DETERMINATION METHODS

\begin{tabular}{|c|c|c|c|c|}
\hline Test Date & $\begin{array}{c}\text { Average } \\
\text { Test } \\
\text { Pressure, } \\
\text { psig } \\
\end{array}$ & $\begin{array}{c}\text { Leakage Rate, } \\
\text { in } \% \\
\text { Reference } \\
\text { Volume } \\
\end{array}$ & $\begin{array}{c}\text { Leakage Rate } \\
\text { in } \% \\
\text { Absolute } \\
\end{array}$ & $\begin{array}{c}\text { Test } \\
\text { Duration, } \\
\text { hr } \\
\end{array}$ \\
\hline $5-11-64$ & 5.7 & 1.6 & 1.7 & 5 \\
\hline $5-12-64$ & 5.7 & 1.1 & 0.9 & 8 \\
\hline $5-13-64$ & 14.2 & 0.9 & 1.0 & 4 \\
\hline $5-19-64$ & 6.1 & 0.20 & 0.27 & 3 \\
\hline $5-22-64$ & 5.95 & 0.21 & 0.26 & 4 \\
\hline $5-23-64$ & 14.2 & 0.90 & 0.88 & 16 \\
\hline $5-28-64$ & 14.3 & 0.43 & 0.54 & 12 \\
\hline
\end{tabular}

The expression used for computing leakage rates with the Absolute Method was

$$
\mathrm{L}=\left[1-\frac{\mathrm{P}_{2}-\left(\mathrm{P}_{\mathrm{v} 2}-\mathrm{P}_{\mathrm{v} 1}\right)}{\mathrm{P}_{1}} \times \frac{\mathrm{T}_{1}}{\mathrm{~T}_{2}}\right] 100
$$

where $L$ is leakage rate in percent. The development of this expression has been given elsewhere. $(4,5)$

The leakage rates are expressed in percent per test length; i.e., on May 11, 1964 the test lasted for $5 \mathrm{hr}$, and during this time the leakage rate was $1.6 \%$ as computed by the Reference Volume Method and $1.7 \%$ as computed by the Absolute Method. The two methods give comparable results for all tests.

A further comparison between the two techniques is given in Figure 3. In this figure the leakage rate, as determined by the two methods from the results of the final test, are compared each $2 \mathrm{hr}$ for the duration of the test. The results are cumulative, i.e., the test began at 9:00 a.m.; the estimate at 11:00 a.m. included $2 \mathrm{hr}$, and the estimate at 1:00 p.m. included $4 \mathrm{hr}$. 


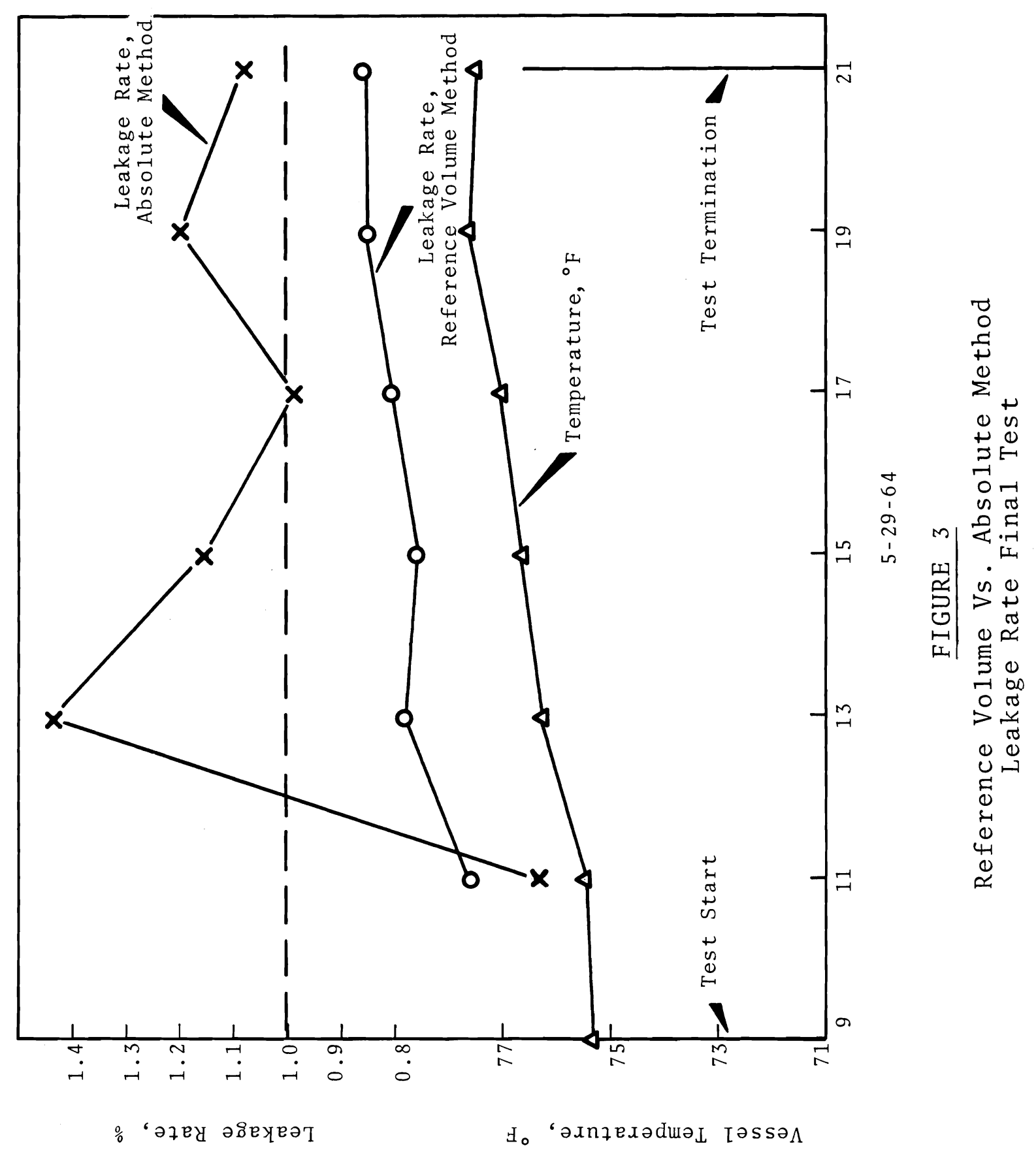


Thus the last comparison is between the final estimates of the leakage rate. The Absolute Method provided slightly higher estimates, although after $12 \mathrm{hr}$ these estimates appeared to be decreasing. Shown in Figure 4, the average vessel temperature increased slowly by about $2{ }^{\circ} \mathrm{F}$ during the test.

\section{The Significance of Vapor Pressure Measurements}

At the temperatures occurring during the tests, about $22 \mathrm{ft}^{3}$ of water vapor were released into the vessel for each pound of water evaporated. During the final leakage rate test over a $12 \mathrm{hr}$ period, approximately $30 \mathrm{lb}$ of water evaporated from unknown sources as all water surfaces in the vessel had been eliminated before the test. The leakage rate estimate was increased by about $0.1 \%$ as a result of recognizing the contribution from the water vapor.

If $60 \mathrm{lb}$ ( 7 1/4 gal) had evaporated and had been detected over the same $12 \mathrm{hr}$ period, the leakage rate estimated from the same pressure data would have exceeded the test limit of $1 \%$. For tests conducted over extended periods, changes in the water vapor content can make significant changes in the estimate of the leakage rate because the vapor volume change can be a substantial fraction of the observed leakage volume.

As indicated in the section on error analysis, the estimated errors associated with the measurements of water vapor pressure are the largest contributors to the uncertainty of the results. The errors are due in part to the precision of the instrumentation available but are primarily inherent in the uncertainty in obtaining a representative measurement of vapor pressure in a large volume. This error is inherent regardless of the control over changes in vapor that can be maintained and of the accuracy in the vapor pressure measurements. 


\section{CONCLUSIONS}

Vapor pressure measurements can be eliminated from the direct evaluation of the results. If accurate measurements of vesse1 and differential pressures can be obtained over brief time intervals and if stable temperatures and vapor pressures exist in the same relatively short time interval, this elimination is possible.

Reliable leakage rate measurements can be obtained in a very short time if high resolutions in the absolute and differential pressure measurement are available. This method assures, of course, that changes in vapor pressure can be ignored, as stated above. On the tests completed at PRTR, a five wheel digital readout device on the differential manometer indicated pressure differentials to the nearest 0.002 in. water. So uniform was the change in differential pressure that preliminary leakage rates projected to $24 \mathrm{hr}$ could be predicted from data obtained over intervals as short as 1 to 3 min.

Leakage rates were estimated from data obtained over 15 min intervals using the following expression:

$$
\% \text { Leakage }=\frac{\Delta P_{c 2}-\Delta P_{c 1}}{P_{1}},
$$

where the symbols have the same meaning as in Appendix III. Figure 4 illustrates the results.

The average leakage rate for the $12 \mathrm{hr}$ period computed in this manner was $0.82 \%$ with a $0.025 \%$ standard deviation about the mean. The center ordinates given in inches of water refer to the corresponding differential pressures accumulated over the 15 min intervals. When determining leakage rates in this manner, a statistical review of the results is necessary to properly determine their precision( 7 ) and the amount of data that must 


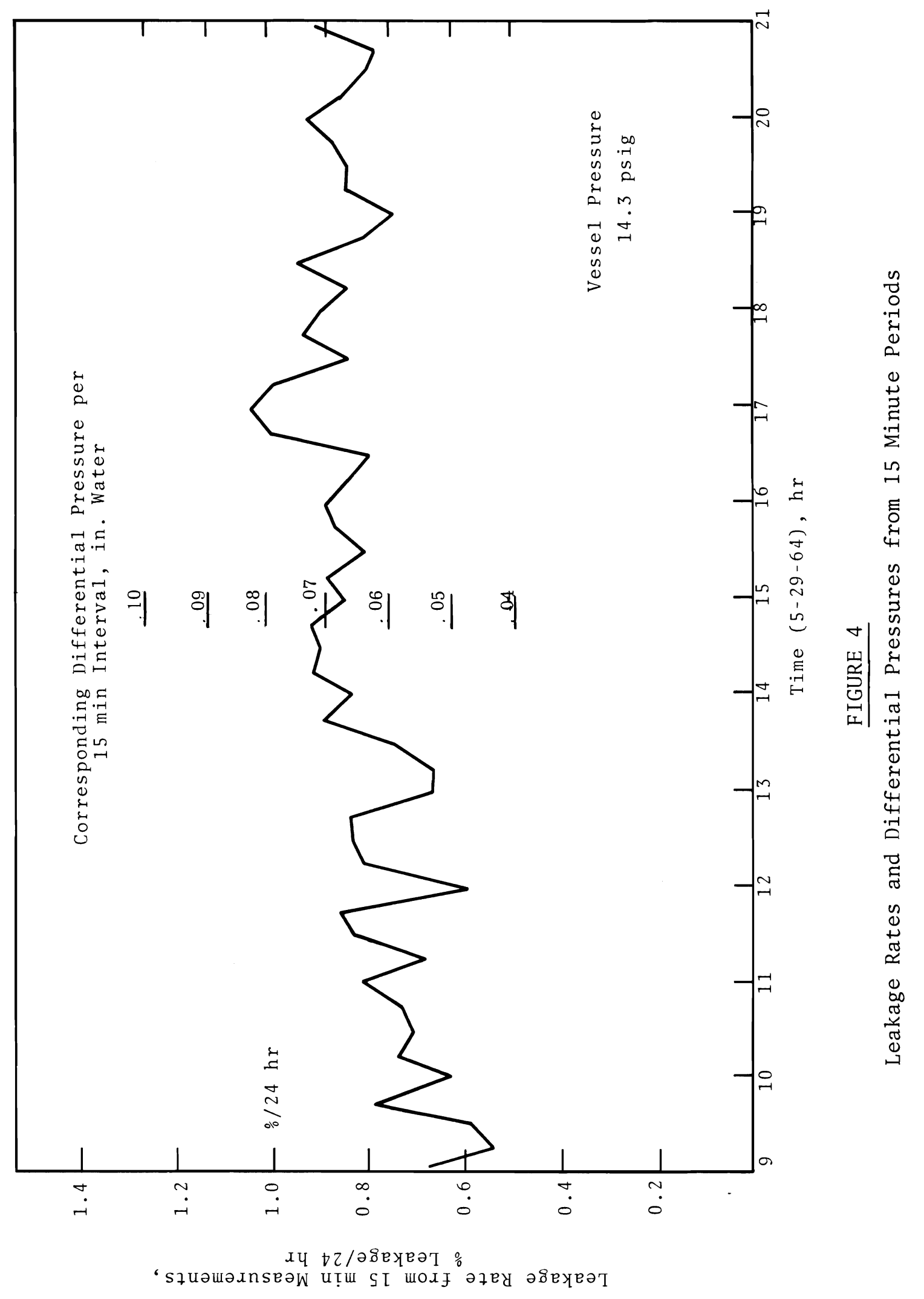


be accumulated (length of test) in order to reach the required accuracy. In order to produce the certainty criteria or precision established for the test, either the data must be narrowly dispersed about the computed mean, or a sufficient sampling must be completed.

From the final test, the following tabulation in Table XI summarizes the statistical analysis completed for the leakage rates computed from pressure measurements determined over the 15 min intervals. The data were arbitrarily assumed to follow a normal distribution.

\section{$\underline{\text { TABLE XI }}$ \\ SUMMARY OF STATISTICAL ANALYSIS \\ OF LEAKAGE RATES}

\begin{tabular}{|c|c|c|c|c|c|}
\hline $\begin{array}{c}\text { Time } \\
\text { Interval } \\
\text { (24 hr Clock) }\end{array}$ & $\begin{array}{l}\text { No. of } \\
\text { Samples }\end{array}$ & $\begin{array}{c}\text { Average } \\
\text { Leakage } \\
\text { Rate, } \\
\text { X }\end{array}$ & $\begin{array}{r}\text { Standard } \\
\text { Deviation } \\
0 \\
\end{array}$ & $\begin{array}{l}95 \% \\
\text { Confi- } \\
\text { dence } \\
1.96 \% \\
\end{array}$ & $\begin{array}{c}\text { Fractiona } 1 \\
\text { Standard } \\
\text { Deviation (9) } \\
\sigma \quad X \\
\end{array}$ \\
\hline $1000-1100$ & 4 & .75 & .08 & .16 & $11 \%$ \\
\hline $1000-1200$ & 8 & .75 & .12 & .23 & $16 \%$ \\
\hline $1000-1300$ & 12 & .76 & .10 & .20 & $13 \%$ \\
\hline $1000-1400$ & 16 & .77 & .10 & .20 & $13 \%$ \\
\hline $1000-1500$ & 20 & .79 & .10 & .20 & $11 \%$ \\
\hline $1000-1600$ & 24 & .81 & .09 & .18 & $11 \%$ \\
\hline $1000-1700$ & 28 & .82 & .10 & .20 & $12 \%$ \\
\hline $1000-1800$ & 32 & .83 & .10 & .20 & $12 \%$ \\
\hline $1000-2100$ & 44 & .83 & .09 & .18 & $11 \%$ \\
\hline
\end{tabular}

Table XI shows that within 3 to $5 \mathrm{hr}$ the dispersion about the mean had reached an equilibrium as indicated by either the $95 \%$ confidence level ( $1.96 \sigma)$ or the fractional standard deviation. Figure 4 and Table XI also indicate that temperature 
equilibrium probably wasn't reached until about 1330 to $1400 \mathrm{hr}$. The leakage rate for the 1 ast $7 \mathrm{hr}(1400-2100)$ was $0.87 \pm 0.12 \%$ at the $95 \%$ confidence level.

Less dispersion of the results is believed inherent in the method than indicated above. The raw data* was manually logged by console operators rotating on 1 hrshifts. They had to answer phones, to respond to off-normal annunciators, and to read periodically a small register. A significant increase in the precision is believed possible with a digital print out device with the print cycle automatically timed. The capability of the method to reduce significantly the length of time required to determine the leakage rate accurately was not foreseen, and such equipment was not provided.

Additional precision in instrumentation is also possible. The vessel gage pressure could have been obtained with an instrument similar to that used for the differential pressure, thus increasing the resolution by an order of magnitude. A differential barometer, used during part of these tests, provided resolution to the nearest $0.05 \mathrm{mbars}(\simeq 0.02$ in. water) so that the absolute vessel pressure could have been determined to the nearest 0.03 in. out of 800 in. of water.

The added precision can result in reliable estimates of leakage rate in relatively short time intervals where, as above, the leakage rate would be determined simply by the ratio

$$
\frac{\Delta P_{C_{2}}-\Delta P_{C 1}}{.} P_{1}
$$

in which both parameters represent accurately conditions of large volumes. (See Equation 2C, Appendix III.)

* Data from servomanometer for $\Delta \mathrm{P}$ measurements only. 
In the past, leakage rate measurements using the reference volume have normally been extended to $24 \mathrm{hr}$ to permit similarly reoccurring temperatures to develop so that data may be compared under similar conditions. Vapor pressure measurements are norma11y included in estimating the leakage rate. However, if reasonable care is taken in designing the reference volume, in conducting the test (establishing stable conditions), and in obtaining precise measurements, a $24 \mathrm{hr}$ test period with the accompanying uncertainties in vapor pressure change is believed unnecessary.

The specifications for allowable acceptable leakage rates would have to be changed correspondingly. For example, the allowable leakage rate could be given as a percent of the contained volume to a specified accuracy at the pressure of interest. If required, the method of extrapolating to allowable leakage rates at other pressures would be included. Of course, time would be a factor but not a stated factor, and it would be flexible depending upon the effort put into the test. The test for leakage rate would last only long enough to satisfy the precision agreed upon for the results as determined by a statistical analysis of the data.

It is proposed that leakage rates on large containment vessels can be quoted with good precision from the results of a series of brief measurements conducted over periods lasting considerably less than $24 \mathrm{hr}$.

\section{ACKNOWLEDGEMENT}

The suggestions and the technical review provided by the Nuclear Safety and Engineering Section and H. E. Hanthorn of that section were essential in the preparation of this report and are gratefully acknowledged. 


\section{REFERENCES}

1. Final Pressure Test Data, Results and Conclusions, Containment Vessel, Plutonium Recycle Reactor, 305-X-3 Building, BPF-15013. American Pipe and Construction Company, Portland, Oregon, June 1959.

2. R. G. Clark. Evaluation of Containment Penetrations at the Plutonium Recycle Test Reactor, HW-78491. General Electric Company, Richland, October 1, 1963.

3. L. T. Pedersen. Unpublished Data, Battelle-Northwest Laboratory, April 9, 1964. (Letter to J. E. Hard titled "Additional Preparations for Containment Vessel Leak Rate Test.")

4. E. G. Keshock and C. E. DeBogdon. Leak Rate Testing of the NASA Plum Brook Reactor Containment Vesse1, NASA TN D-1731. Lewis Research Center, July 1963.

5. R. F. Griffin and G. H. Dyer. Unpublished Data. (Reactor Containment Handbook, Chapter 7, "Containment Proof Testing".)

6. R. D. Brittain. Reactor Containment, ANL-5948. Argonne National Laboratory, May $1 \overline{959}$.

7. H. E. Hanthorn. Unpublished Data, Battelle-Northwest Laboratory, January 7, 1965. (Private Communication)

8. G. C. Robinson. "Containment Vessel Leak Rate Testing," AEC Publication Nuclear Safety, Vol. 6, No. 1, p. 69. 1964.

9. Yardley Beers. Introduction to the Theory of Error, Addison-Wesley Publishing Company, Reading, Mass. 
APPENDIX I

INSTRUMENTATION 


\section{INSTRUMENTATION}

(1) Pressure Gage - Wallace and Tiernan, Model No. FA-145, Serial No. HH-11878, Range 0-408 in. Custom ordered for 0-415 in.

(2) Barometric Pressure - Wallace and Tiernan, Model No. FA-112, Serial No. GG-09978, Range 450-1030 mbars. Differential Manometer, Wallace and Tiernan, Model No. FA-88, Serial No. 5279 B, setting Range 700-1065 mbars. Differential range \pm 5 mbars, minimum reading 0.1 mbars.

(3) Dew Point - Five Dial Wheatstone Bridge, Leeds and Northrup, Model No. 4725; 1 1/2 V Eveready Telephone Battery; Galvanometer, Electronic, Kintel, Model 204-A; Dew Cel1, Dew Probe Sensor, SS129-B, MinneapolisHoneywe11 Regulator Company.

(4) Temperature - Six Iron-Constant Thermocouples; Potentiometer, Type K-3 Universal Potentiometer, Catalog No. 7553, Serial No. 1500440, Leeds and Northrup Company, Philadelphia. Electronic Galvanometer, Leeds and Northrup, D. C. Microvolt Amplifier, Catalog No. 9885, Serial No. 1321179. Standard Cel1, The Eppley Laboratory, Inc., No 451111, Catalog No. 100 . Battery, Willard, $2 \mathrm{~V}$ wet cell. Ref. Junction, dewar flask, ice bath.

(5) Differential Pressure - Servomanometer, Exactel Servomanometer, 0-120 in., Mode1 C51201-D, Serial No. 628.

(6) Flow Meters - Fischer-Porter, Series 10A2700, Flowrator Meters, Tube FP-1-35-G-10, Float 1-GSVT-64.

Brooks Rotameter, Tube R-8M-25-4 with Float St. St. (8RS-14);0-7 scfm。

(7) Leak Detectors - C-Leak, Chemical Sundries Inc., Chicago, Illinois。 Ultrasonic Translator, Delcon Corporation, Palo Alto, California.

(8) Potting Compound - Epoxy Compound EC 1291, Minnesota Mining and Mfg. Co., Detroit, Michigan.

Plastic Steel A, Devcon Corporation, Danvers, Massachusetts. 
APPENDIX II

CONTAINMENT VESSEL PENETRATIONS 


\section{CONTAINMENT VESSEL PENETRATIONS}

\section{Penetration and Contents}

1. $480 \mathrm{~V}$ main power conductors.

2. $480 \mathrm{~V}$ main power conductors, miscellaneous control wire.

3. Miscellaneous control wire.

4. Multiconductor cables.

5. Spare - not in use.

6. Instrument air tubing runs - 10 bundles of 10 lines each.

7. Spare - not in use.

8. FERTF heater leads.

9. Miscellaneous control wires for gas 1oop.

10. Abandoned - contained 8 bundles of 10 instrument air lines each.

11. Spare - not in use.

12. $2400 \mathrm{~V}$ power conductors.

13. $2400 \mathrm{~V}$ power conductors.

14. $2400 \mathrm{~V}$ power conductors.

15. $2400 \mathrm{~V}$ power conductors.

16. Communication wire runs

17. Communication wire runs.

18. Spare - not in use.

19. Instrument air line bundle - new installation with bulkhead type fittings.

20. $480 \mathrm{~V}$ main power conductors, miscellaneous wires.

21. Television camera cable.

22. $2400 \mathrm{~V}$ power conductors.

23. Communication wire runs.

24. Communication wire runs.

25. Area radiation monitoring signal leads, miscellaneous wire.

26. Multiconductor cables.

27. Multiconductor cables

28. Multiconductor cables.

29. Coaxial cables。

30. Multiconductor cables.

31. Large single conductor cable (spare).

32. Large single conductor cable (spare).

33. Miscellaneous individual control wires (30).

33a. Miscellaneous individual control wires (25).

34. Spare - not in use.

35. Spare - not in use.

36. Spare - not in use.

37. Spare - not in use.

38. Spare - not in use.

39. Spare - not in use.

40. Spare - not in use.

41. Multiconductor cables.

42. Gas loop thermocouple and control wire runs.

43. Gas loop thermocouple wire runs.

44. Spare penetrations - not in use.

45. Spare penetrations - not in use. 
Vesse1 Side

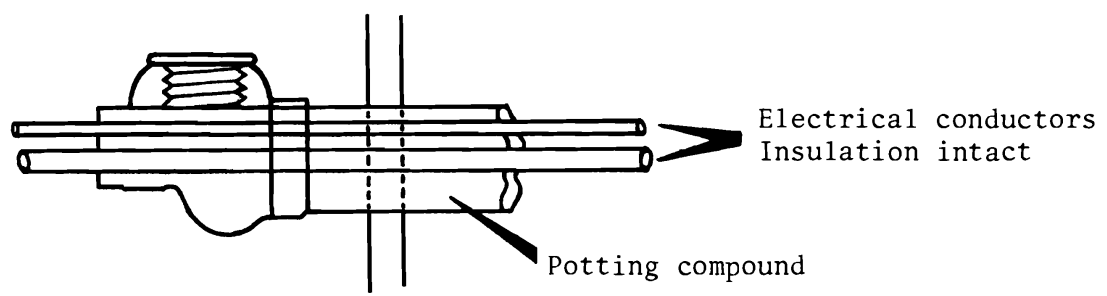

Pipe penetration with electrical conductors passing through

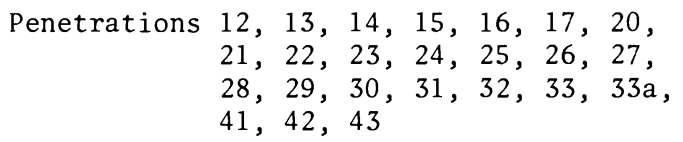

Vessel Side

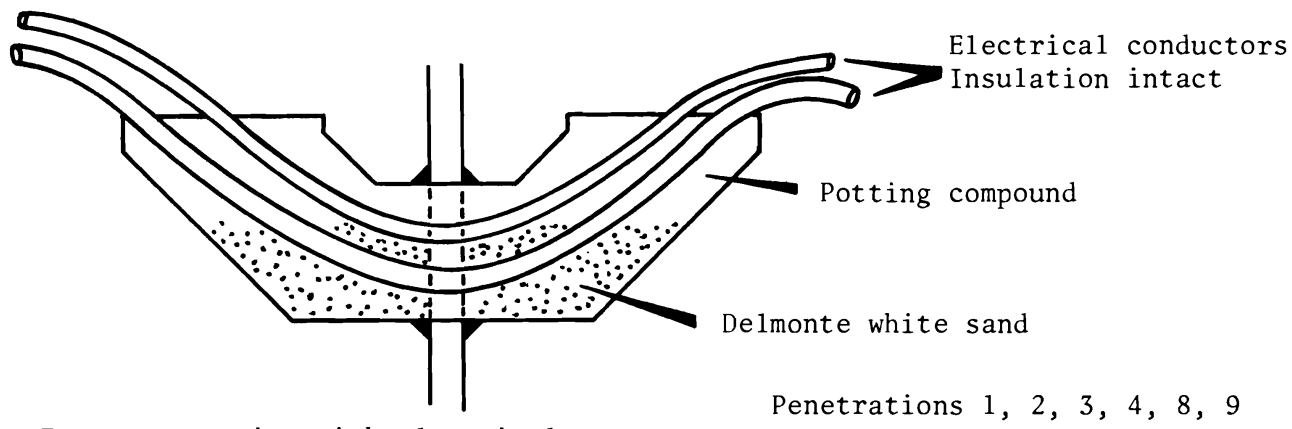

Tray penetration with electrical

conductors passing through

Vessel Side

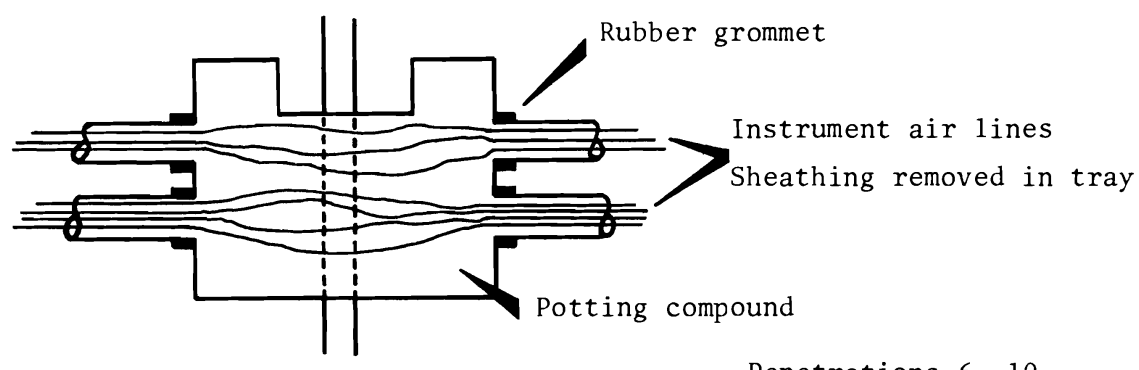

Tray penetration with instrument

Penetrations 6,10

air lines passing through

\section{FIGURE 5}

Penetration Designs - PRTR Containment Vessel 
APPENDIX III

DEVELOPMENT OF THE EXPRESSION FOR LEAKAGE RATE 


\section{DEVELOPMENT OF THE EXPRESSION FOR LEAKAGE RATE}

The development of the expressions for determining the leakage rate by the reference volume method has been given in considerable detail elsewhere. $(4,5)$ The following summarizes the method, which starts with the perfect gas laws. Reference vessel parameters are given with a prime and the subscripts 1 and 2 are used to denote the same parameters after a lapse of time.

For the reference volume,

$$
\begin{aligned}
& \mathrm{P}_{1}^{\prime} \mathrm{V}_{1}^{\prime}=\mathrm{W}_{1}^{\prime} \mathrm{RT}_{1}^{\prime}, \\
& \mathrm{P}_{2}^{\prime} \mathrm{V}_{2}^{\prime}=\mathrm{W}_{2}^{\prime} \mathrm{RT}_{2}^{\prime},
\end{aligned}
$$

and for the containment vessel,

$$
\begin{aligned}
& \mathrm{P}_{1} \mathrm{~V}_{1}=\mathrm{w}_{1} \mathrm{RT}_{1}, \\
& \mathrm{P}_{2} \mathrm{~V}_{2}=\mathrm{w}_{2} \mathrm{RT}_{2} .
\end{aligned}
$$

Note that in the above, $V^{\prime}, W^{\prime}, V$, and $R$ may be assumed constants; i.e.,

$$
\begin{aligned}
& \mathrm{V}_{1}^{\prime}=\mathrm{V}_{2}^{\prime}=\mathrm{V}^{\prime}, \\
& \mathrm{W}_{1}^{\prime}=\mathrm{W}_{2}^{\prime}=\mathrm{W}^{\prime}, \\
& \mathrm{v}_{1}=\mathrm{v}_{2}=\mathrm{V},
\end{aligned}
$$

and $\mathrm{R}$ is a universal constant (for both systems).

Initially, the difference in pressures between the vessels is

$$
\begin{aligned}
& \Delta \mathrm{P}_{1}=\mathrm{P}_{1}^{\prime}-\mathrm{P}_{1}, \\
& \Delta \mathrm{P}_{1}=\mathrm{R}\left(\frac{\mathrm{W}^{\prime} \mathrm{T}_{1}^{\prime}}{\mathrm{V}^{\prime}}-\frac{\mathrm{W}_{1} \mathrm{~T}_{1}}{\mathrm{~V}}\right),
\end{aligned}
$$


from which

$$
W_{1}=\frac{V}{T_{1}}\left(\frac{W^{\prime} T_{1}^{\prime}}{V^{\prime}}-\frac{\Delta P_{1}}{R}\right)
$$

Similarly

$$
W_{2}=\frac{V}{T_{2}}\left(\frac{W^{\prime} T_{2}^{\prime}}{V^{\prime}}-\frac{\Delta P_{2}}{R}\right)
$$

Then,

$$
\frac{\mathrm{W}_{1}-\mathrm{W}_{2}}{\mathrm{~W}_{1}}=\frac{\mathrm{P}_{1}^{\prime} \mathrm{T}_{1}}{\mathrm{P}_{1} \mathrm{~T}_{1}^{\prime}}\left(\frac{\mathrm{T}_{1}^{\prime}}{\mathrm{T}_{1}}-\frac{\mathrm{T}_{2}^{\prime}}{\mathrm{T}_{2}}\right)+\frac{\mathrm{T}_{1}}{\mathrm{P}_{1}}\left(\frac{\Delta \mathrm{P}_{2}}{\mathrm{~T}_{2}}-\frac{\Delta \mathrm{P}_{1}}{\mathrm{~T}_{1}}\right)
$$

where $\frac{W_{1}-W_{2}}{W_{1}}$ is the fractional leakage during the peroid of the test.

$\frac{W_{1}-W_{2}}{W_{1}} \times 100$ gives the leakage rate in percent.

Referring to Equation (1), if it is assumed that the temperatures in the reference volume and the vessel are equal to each other initially and again (if not continuously) at the end of the test, the first term becomes zero and

$$
\frac{\mathrm{W}_{1}-\mathrm{W}_{2}}{\mathrm{~W}_{1}}=\frac{\mathrm{T}_{1}}{\mathrm{P}_{1}}\left(\frac{\Delta \mathrm{P}_{2}}{\mathrm{~T}_{2}}-\frac{\Delta \mathrm{P}_{1}}{\mathrm{~T}_{1}}\right),
$$

or

$$
\frac{\mathrm{W}_{1}-\mathrm{W}_{2}}{\mathrm{~W}_{1}}=\frac{\Delta \mathrm{P}_{2}}{\mathrm{P}_{1}}\left(\frac{\mathrm{T}_{1}}{\mathrm{~T}_{2}}-\frac{\Delta \mathrm{P}_{1}}{\mathrm{P}_{1}}\right),
$$

or

$$
\frac{\mathrm{W}_{1}-\mathrm{W}_{2}}{\mathrm{~W}_{1}}=\frac{1}{\mathrm{P}_{1}}\left(\Delta \mathrm{P}_{2} \frac{\mathrm{T}_{1}}{\mathrm{~T}_{2}}-\Delta \mathrm{P}_{1}\right) \text {. }
$$


Equations (2a), (2b), and (2c) include a temperature measurement or at least knowledge that the temperature in the vessel at two different times is identical.

However, Equation (1) can he handled algebraically by substituting the term $\left(\Delta \mathrm{P}_{1}+\mathrm{P}_{1}\right)$ for $\mathrm{P}_{1}^{\prime}$, then dividing numerator and denominator by $\left(\Delta \mathrm{P}_{2}+\mathrm{P}_{2}\right)$, and without making any assumptions the following expression can be developed.

$$
\frac{\mathrm{W}_{1}-\mathrm{W}_{2}}{\mathrm{~W}_{1}}=1-\frac{\mathrm{P}_{2}}{\mathrm{P}_{1}}\left(\frac{\mathrm{P}_{1}+\Delta \mathrm{P}_{1}}{\mathrm{P}_{2}+\Delta \mathrm{P}_{2}}\right)\left[\frac{\mathrm{T}_{1}}{\frac{\mathrm{T}_{1}^{\prime}}{\mathrm{T}_{1}}} \times \frac{\mathrm{T}_{2}^{\prime}}{\mathrm{T}_{2}}\right] \text {. }
$$

In Equation (3) above, if it is assumed that, at the time of the measurement of the other parameters, the temperatures in the two volumes are equal; i.e., $\mathrm{T}_{1}=\mathrm{T}_{1}^{\prime}$ initially and $\mathrm{T}_{2}=\mathrm{T}_{2}^{\prime}$ later, then the Reference Volume Method yields an expression independent of temperature.

$$
\frac{W_{1}-W_{2}}{W_{1}}=1-\frac{P_{2}}{P_{1}}\left(\frac{P_{1}+\Delta P_{1}}{P_{2}+\Delta P_{1}}\right) \text {. }
$$

The above expression, when a correction for vapor pressure $\left(\mathrm{P}_{\mathrm{V}}\right)$ is included, is written as

$$
\frac{W_{1}-W_{2}}{W_{1}}=1-\frac{P_{2}-\left(P_{v 2}-P_{v 1}\right)}{P_{1}} \times \frac{P_{1}+\Delta P_{1}}{P_{2}+\Delta P_{2}}
$$

It is revealing to point out that the expression for the leakage rate with the Absolute Method using the same development is

$$
\frac{W_{1}-W_{2}}{W_{1}}=1-\frac{P_{2}-\left(P_{v 2}-P_{v 1}\right)}{P_{1}} \times \frac{T_{1}}{T_{2}} \text {. }
$$

Thus, $\frac{\mathrm{T}_{1}}{\mathrm{~T}_{2}}$ and $\frac{\mathrm{P}_{1}+\Delta \mathrm{P}_{1}}{\mathrm{P}_{2}+\Delta \mathrm{P}_{2}}$ function identically. The reference volume, if properly installed, serves as an averaging gas thermometer. Pressure (P) 
and differential pressure $(\Delta \mathrm{P})$ can be easily measured to the precision and the accuracy required with single measurements, which are representative of the entire volumes; whereas, representative temperatures cannot be measured to the same precision as easily.

Lack of precision in the above expression involving only pressures is solely due to changes in water vapor pressure and to the difficulty in obtaining a volume average of this variable. Eliminating the vapor pressure measurement increases the precision of the measurement significantly; this can be done if the data are obtained in a short time interval during which water is neither evaporated or condensed. 
APPENDIX IV

CORRECTION FACTOR FOR THE OBSERVED DIFFERENTIAL PRESSURE 
CORRECTION FACTOR FOR THE OBSERVED DIFFERENTIAL PRESSURI:

The correction factor for the differential pressure is developed as follows. All parameters refer only to the reference volume. Assume that the temperature of the contents of the reference volume remain constant for this development. Then the difference in pressure in the reference volume at two different times, $t_{1}$ and $t_{2}$, due only to a change in volume is $\Delta \mathrm{P}_{\mathrm{X}}$ and will be referred to as $\mathrm{B}$, thus:

$$
\Delta \mathrm{P}_{\mathrm{x}}=\mathrm{B}=\mathrm{P}_{1}-\mathrm{P}_{2}=\mathrm{WRT}\left(\frac{1}{\mathrm{~V}_{1}}-\frac{1}{\mathrm{~V}_{2}}\right) \text {. }
$$

Dividing both sides by $\mathrm{P}_{1}$ or its equivalent, $\frac{\text { WRT }}{\mathrm{V}_{1}}$,

$$
\begin{aligned}
\frac{B}{P_{1}}= & V_{1}\left(\frac{1}{V_{1}}-\frac{1}{V_{2}}\right), \\
B= & P_{1}\left(1-\frac{V_{1}}{V_{2}}\right), \\
V_{1}= & \text { volume of } 475 \mathrm{ft} \text { of } 3 / 4 \text { in. copper tubing, including } \\
& \text { the free space in the top of the cistern, } \\
V_{1}= & \frac{\pi D^{2}}{4} L_{1} ; \\
L_{1}= & 5688 \text { in. }
\end{aligned}
$$

Assume that $V_{2}$ is greater than $V_{1}$ by 1 in. of rise in the manometer 1 eg. For the reference system used in these tests, an increase in volume resulting from a rise in the precision bore (0.750 in.) manometer leg results in a volume $\left(V_{2}\right)$ of $\frac{\pi D^{2} L_{2}}{4}$ in. $^{3}$ Hence

$$
\begin{aligned}
& B=P_{1}\left(1-\frac{L_{1}}{L_{2}}\right), \\
& B=P_{1}(1-0.9998) / i n \text {. of differential pressure change, }
\end{aligned}
$$


when

$$
\left(\frac{\mathrm{L}_{1}}{\mathrm{~L}_{2}}=\frac{5688}{5689}=0.9998\right) \text {. }
$$

Thus, the correction (B) for each inch of change in manometer level $(\Delta P)$ as measured, is

$$
\frac{\mathrm{B}}{\Delta \mathrm{P}}=\mathrm{P}_{1}(0.0002)
$$

In addition to the manometric rise in the servomanometer is the similar rise of oil in the seal pot. The effective change in length is essentially doubled for each inch of rise of oil in the manometer leg. Allowing for the small difference in diameter between the precision bore in the manometer and the copper reference volume tube, $\mathrm{L}_{2}$ now becomes 5690.27 in. and

$$
\frac{B}{\Delta P}=\left(P_{1}\right)(0.0004) ;
$$

or the total correction per reading is

$$
B=\left(P_{1}\right)(0.0004)(\Delta P)
$$

The corrected differential pressure value $\left(\Delta \mathrm{P}_{c}\right)$ for each differential pressure measurement $\Delta \mathrm{P}$ is

$$
\begin{aligned}
& \Delta \dot{P}_{c}=\Delta P+B, \\
& \Delta P_{c}=\Delta P\left(1+0.0004 P_{1}\right) .
\end{aligned}
$$


APPENDIX V

DATA SHEET - FINAL TEST 
DATA SHEET - FINAL

\begin{tabular}{|c|c|c|c|c|c|c|c|}
\hline \multirow{2}{*}{$\begin{array}{l}\text { Time } \\
\text { hr clock) }\end{array}$} & \multicolumn{2}{|c|}{ Barometer } & \multirow{2}{*}{$\begin{array}{l}\text { Vesse1 } \\
\text { Pressure } \\
\text { in. } \mathrm{H}_{2} \mathrm{O} \\
\text { (gage) }\end{array}$} & \multirow{2}{*}{$\begin{array}{c}\text { Vessel } \\
\text { Pressure } \\
\text { in. } \mathrm{H}_{2} \mathrm{O} \\
\text { (absolute) }\end{array}$} & \multirow{2}{*}{$\begin{array}{c}\text { Differential } \\
\text { Pressure } \\
\text { in. } \mathrm{H}_{2} \mathrm{O} \\
\text { (uncorrected) }\end{array}$} & \multirow{2}{*}{$\begin{array}{l}\text { Differential } \\
\text { Pressure, } \\
\text { in. } \mathrm{H}_{2} \mathrm{O} \\
\text { (corrected) }\end{array}$} & \multirow{2}{*}{$\begin{array}{l}\text { Vapor } \\
\text { Pressure, } \\
\text { in. } \mathrm{H}_{2} \mathrm{O} \\
\text { (average) }\end{array}$} \\
\hline & mbars & in. $\mathrm{H}_{2} \mathrm{O}$ & & & & & \\
\hline 0800 & 999.0 & 401.1 & 397.1 & 798.2 & 1.201 & 1.601 & 8.72 \\
\hline 0830 & 999.5 & 401.3 & 397.0 & 798.3 & 1.247 & 1.648 & 8.76 \\
\hline 0900 & 1000.0 & 401.5 & 397.0 & 798.5 & 1.325 & 1.766 & 8.77 \\
\hline 0930 & 1000.0 & 401.5 & 397.0 & 798.5 & 1.394 & 1.858 & 8.78 \\
\hline 1000 & 1000.0 & 401.5 & 396.9 & 798.4 & 1.480 & 1.972 & 8.76 \\
\hline 1030 & 1000.1 & 401.5 & 396.8 & 798.3 & 1.568 & 2.080 & 8.76 \\
\hline 1100 & 1000.3 & 401.6 & 396.7 & 798.3 & 1.661 & 2.213 & 8.76 \\
\hline 1130 & 1000.4 & 401.7 & 396.7 & 798.4 & 1.752 & 2.335 & 8.78 \\
\hline 1200 & 1000.3 & 401.6 & 396.6 & 798.2 & 1.850 & 2.465 & 8.80 \\
\hline 1300 & 1000.0 & 401.5 & 396.6 & 798.1 & 2.032 & 2.708 & 8.85 \\
\hline 1330 & 1000.0 & 401.5 & 396.6 & 798.1 & 2.117 & 2.821 & 8.87 \\
\hline 1400 & 1000.0 & 401.5 & 396.6 & 798.1 & 2.221 & 2.959 & 8.85 \\
\hline 1430 & 999.9 & 401.5 & 396.6 & 798.1 & 2.330 & 3.105 & 8.82 \\
\hline 1500 & 999.5 & 401.3 & 396.75 & 798.0 & 2.436 & 3.246 & 8.75 \\
\hline 1530 & 999.2 & 401.2 & 396.8 & 798.0 & 2.537 & 3.381 & 8.90 \\
\hline 1600 & 999.2 & 401.2 & 396.8 & 798.0 & 2.642 & 3.521 & 8.92 \\
\hline 1630 & 999.1 & 401.1 & 397.2 & 798.3 & 2.740 & 2.652 & 9.03 \\
\hline 1700 & 999.1 & 401.1 & 397.3 & 798.4 & 2.862 & 2.814 & 9.02 \\
\hline 1730 & 998.7 & 401.0 & 397.5 & 798.5 & 2.972 & 3.961 & 9.03 \\
\hline 1800 & 998.7 & 401.0 & 397.5 & 798.5 & 3.082 & 4.108 & 9.00 \\
\hline 1830 & 998.7 & 401.0 & 397.4 & 798.5 & 3.189 & 4.250 & 9.02 \\
\hline 1900 & 998.7 & 401.0 & 397.2 & 798.2 & 3.282 & 4.374 & 9.05 \\
\hline 1930 & 998.7 & 401.0 & 397.1 & 798.1 & 3.392 & 4.520 & 9.02 \\
\hline 2000 & 999.3 & 401.2 & 396.5 & 797.6 & 3.489 & 4.649 & 9.02 \\
\hline 2030 & 999.8 & 401.5 & 396.4 & 797.9 & 3.587 & 4.779 & 9.05 \\
\hline 2100 & 1000.0 & 401.5 & 396.1 & 797.6 & 3.689 & 4.915 & 9.13 \\
\hline
\end{tabular}




\begin{tabular}{|c|c|c|c|c|c|c|c|c|c|c|c|c|c|}
\hline \multirow{2}{*}{$\begin{array}{l}\text { Time } \\
(24 \mathrm{hr} \\
\text { clock) } \\
\end{array}$} & \multicolumn{2}{|c|}{ Thermocouple \# 1} & \multicolumn{2}{|c|}{ Thermocouple \#2 } & \multicolumn{2}{|c|}{ Thermocouple \# 3} & \multicolumn{2}{|c|}{ Thermocouple \#4 } & \multicolumn{2}{|c|}{ Thermocouple \# 5} & \multicolumn{2}{|c|}{ Thermocouple \#6 } & $\begin{array}{c}\text { Average, } \\
{ }^{\circ} \mathrm{F}\end{array}$ \\
\hline & $\mathrm{mv}$ & + & $\mathrm{miv}$ & $\mathrm{F}$ & miv & 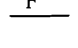 & IIIV & & $\mathrm{mV}$ & & & & \\
\hline 0800 & 1.3436 & 79.3 & 1.2740 & 76.9 & 0.9496 & 65.7 & 1.1645 & 73.2 & 1.1204 & 71.6 & 1.1305 & 72.0 & 74.45 \\
\hline 0830 & 1.3473 & 79.5 & 1.2787 & 77.0 & 0.9764 & 66.6 & 1.1845 & 73.9 & 1.1477 & 72.6 & 1.1519 & 72.8 & 75.07 \\
\hline 0900 & 1.3462 & 79.4 & 1.2839 & 77.3 & 0.9942 & 67.2 & 1.1954 & 74.2 & 1.1619 & 73.1 & 1.1529 & 72.8 & 75.33 \\
\hline 0930 & 1.3590 & 79.9 & 1.2724 & 76.8 & 0.9896 & 67.1 & 1.2022 & 74.4 & 1.1631 & 73.2 & 1.1487 & 72.6 & 75.33 \\
\hline 1000 & 1.3458 & 79.4 & 1.2759 & 77.0 & 1.0212 & 68.2 & 1.2109 & 74.8 & 1.1748 & 73.3 & 1.1519 & 72.7 & 75.57 \\
\hline 1030 & 1.3425 & 79.3 & 1.2717 & 76.8 & 1.0237 & 68.3 & 1.2136 & 74.8 & 1.1750 & 73.6 & 1.1473 & 72.6 & 75.57 \\
\hline 1130 & 1.3512 & 79.6 & 1.2822 & 77.2 & 1.0396 & 68.8 & 1.2276 & 75.3 & 1.1743 & 73.5 & 1.1308 & 72.0 & 75.73 \\
\hline 1200 & 1.3494 & 79.5 & 1.2744 & 76.9 & 1.0686 & 69.8 & 1.2363 & 75.6 & 1.1863 & 74.0 & 1.1589 & 73.0 & 76.13 \\
\hline 1300 & 1.3434 & 79.3 & 1.2724 & 76.9 & 1.0500 & 69.2 & 1.2425 & 75.8 & 1.2000 & 74.4 & 1.1764 & 73.6 & 76.20 \\
\hline 1330 & 1.3423 & 79.3 & 1.2722 & 76.9 & 1.0788 & 70.2 & 1.2444 & 75.9 & 1.1677 & 73.3 & 1.0850 & 70.4 & 75.67 \\
\hline 1400 & 1.2375 & 79.5 & 1.2736 & 76.9 & 1.0742 & 70.0 & 1.2475 & 76.0 & 1.1541 & 72.8 & 1.1043 & 71.1 & 75.72 \\
\hline 1430 & 1.3500 & 70.6 & 1.2803 & 77.2 & 1.0992 & 70.9 & 1.2572 & 76.4 & 1.1763 & 73.6 & 1.1200 & 71.6 & 76.22 \\
\hline 1500 & 1.3504 & 79.6 & 1.2813 & 77.2 & 1.1085 & 71.2 & 1.2609 & 76.5 & 1.1920 & 74.1 & 1.1524 & 72.8 & 76.57 \\
\hline 1600 & 1.3520 & 79.6 & 1.2355 & 75.6 & 1.0915 & 70.6 & 1.2635 & 76.6 & 1.1890 & 74.0 & 1.1190 & 71.6 & 76.00 \\
\hline 1630 & 1.3572 & 79.8 & 1.2525 & 76.2 & 1.0970 & 70.8 & 1.2715 & 76.8 & 1.2050 & 74.6 & 1.1776 & 73.6 & 76.63 \\
\hline 1700 & 1.3620 & 79.8 & 1.2730 & 76.9 & 1.0790 & 70.2 & 1.2760 & 77.0 & 1.2210 & 75.2 & 1.2075 & 74.6 & 76.97 \\
\hline 1730 & 1.3630 & 80.0 & 1.2735 & 76.9 & 1.0900 & 70.6 & 1.2360 & 75.6 & 1.2335 & 75.6 & 1.2305 & 75.4 & 77.03 \\
\hline 1800 & 1.3652 & 80.1 & 1.2795 & 77.2 & 1.1200 & 71.6 & 1.2825 & 77.2 & 1.2473 & 76.0 & 1.2430 & 75.8 & 77.65 \\
\hline 1830 & 1.3642 & 79.3 & 1.2825 & 77.2 & 1.1140 & 71.4 & 1.2860 & 77.4 & 1.2510 & 76.2 & 1.2535 & 76.2 & 77.74 \\
\hline 1900 & 1.3618 & 80.0 & 1.2770 & 77.0 & 1.0910 & 70.6 & 1.2873 & 77.4 & 1.2612 & 76.5 & 1.2535 & 76.2 & 77.62 \\
\hline 1930 & 1.3615 & 80.0 & 1.2835 & 77.2 & 1.1000 & 71.0 & 1.2912 & 77.6 & 1.2765 & 77.0 & 1.2745 & 76.9 & 77.95 \\
\hline 2000 & 1.3612 & 80.0 & 1.2820 & 77.2 & 1.0790 & 70.2 & 1.2920 & 77.6 & 1.2700 & 76.8 & 1.2570 & 76.4 & 77.70 \\
\hline 2030 & 1.3620 & 80.0 & 1.2755 & 77.0 & 1.0880 & 70.5 & 1.2950 & 77.6 & 1.2605 & 76.5 & 1.2476 & 76.0 & 77.60 \\
\hline 2100 & 1.3570 & 79.8 & 1.2739 & 76.9 & 1.1170 & 71.6 & 1.2950 & 77.6 & 1.2530 & 76.2 & 1.2190 & 75.0 & 77.52 \\
\hline Correct & $1 \mathrm{~S}^{*}$ & +1.0 & & +1.9 & & +1.4 & & +1.3 & & +0.8 & & +1.6 & \\
\hline
\end{tabular}

The above tabulation excludes the corrections noted. For example, at $2100 \mathrm{hr}$ TC \#1 read $1.3570 \mathrm{mV}$ which is equivalent to $79.8{ }^{\circ} \mathrm{F}$. The average temperature given in the last column includes the correction factors.

*From Table II in the text. 
APPENDIX VI

LEAKAGE RATE CALCULATIONS - FINAL TEST 


\section{LEAKAGE RATE CALCULATIONS - FINAL TEST}

The following calculations were made for the final leak rate test completed on May 27 and 28, 1964. Following pressurization of the vesse1 completed at 11:00 p.m. on May 27, equilibrium conditions did not develop rapidly; a faulty containment valve on the chilled water system allowed chilled water to enter the ventilation units. The vessel was cooled unnecessarily for about $2 \mathrm{hr}$ before the cause was recognized and the condition corrected.

Essentially equilibrium temperatures developed by 9:00 a.m., and the test was started. It was terminated $12 \mathrm{hr}$ later at 9:00 p.m.

The vapor pressure measurements were determined by graphically averaging the results. The loss in precision was small.

The initial time $\left(t_{1}\right)$ was 9:00 a.m. The pressure measurements were corrected to inches of water column at $4{ }^{\circ} \mathrm{C}$. The data were

$$
\begin{aligned}
P_{B} & =1000 \text { mbars } x .4015 \text { in. } \mathrm{H}_{2} \mathrm{O} \\
& =401.5 \text { in. } \\
P_{G} & =397.0 \text { in } \mathrm{H}_{2} \mathrm{O} \\
\mathrm{P}_{1} & =798.5 \text { in. } \\
\mathrm{P}_{\mathrm{V}_{1}} & =8.77 \text { in } \\
\Delta \mathrm{P}_{1} & =1.748 \text { in. }
\end{aligned}
$$

The final time was 9:00 p.m. The data were:

$$
\begin{aligned}
P_{B} & =1000 \text { mbars } \\
& =401.5 \text { in. } \\
P_{G} & =396.1 \mathrm{in} .
\end{aligned}
$$




$$
\begin{aligned}
& \mathrm{P}_{2}=797.6 \mathrm{in} . \\
& \mathrm{P}_{\mathrm{v} 2}=9.10 \mathrm{in} \text {. } \\
& \Delta \mathrm{P}_{2}=4.866 \mathrm{in} \text {. } \\
& \frac{\text { \%Leakage }}{24 \mathrm{hr}}=100\left[1-\frac{\mathrm{P}_{2}-\left(\mathrm{P}_{\mathrm{v} 2}-\mathrm{P}_{\mathrm{vl}}\right)}{\mathrm{P}_{1}} \times \frac{\mathrm{P}_{1}+\Delta \mathrm{P}_{1}}{\mathrm{P}_{2}+\Delta \mathrm{P}_{2}}\right] \\
& \frac{\mathrm{P}_{2}-\left(\mathrm{P}_{\mathrm{v} 2}-\mathrm{P}_{\mathrm{v}}\right)}{\mathrm{P}_{1}}=\frac{797.6-(9.10-8.77)}{798.5} \\
& =\frac{797.27}{798.5} \\
& =.99846 \\
& \frac{\mathrm{P}_{1}+\Delta \mathrm{P}_{1}}{\mathrm{P}_{2}+\Delta \mathrm{P}_{2}}=\frac{798.5+1.748}{797.6+4.866} \\
& =\frac{800.248}{802.466} \\
& =.99724 \\
& 100(1-.99846 \times .99724)=(1-.99570) 100 \\
& =.43 \\
& \frac{\% \text { Leakage }}{24 \mathrm{hr}}=\frac{24}{12}(.43) \\
& =0.86 \% \text { at } 396.1 \mathrm{in} \text {. } \\
& \frac{\text { Leakage Rate }}{24 \mathrm{hr}}=(0.86) \sqrt{\frac{415}{396.1}} \\
& =.879 \\
& \frac{\text { Leakage Rate }}{24 \mathrm{hr}}=-0.9 \%
\end{aligned}
$$




\section{ONSITE DISTRIBUTION}

\section{Copy Number}

Pacific Northwest Laboratory

\begin{tabular}{|c|c|}
\hline 1 & E. R. Ast ley \\
\hline 2 & D. C. Boyd \\
\hline 3 & J. G. Bradley \\
\hline $4-13$ & R. G. Clark \\
\hline 14 & J. E. Curtis \\
\hline 15 & R. V. Dulin \\
\hline 16 & J. C. Fox \\
\hline 17 & R. C. Frost \\
\hline 18 & G. A. Halseth \\
\hline 19 & H. E. Hanthorn \\
\hline 20 & H. Harty \\
\hline 21 & R. K. Hil1iard \\
\hline 22 & S. K. Hokanson \\
\hline 23 & E. R. Irish \\
\hline 24 & R. T. Jaske \\
\hline 25 & R. L. Junkins \\
\hline $26-29$ & D. R. Koberg \\
\hline 30 & W. R. Lewis \\
\hline 31 & C. E. Linderoth \\
\hline 32 & T. C. Mehas \\
\hline 33 & J. L. McE1roy \\
\hline 34 & D. E. Newby \\
\hline 35 & L. J. Nitteberg \\
\hline 36 & R. H. Purce 11 \\
\hline 37 & W. D. Richmond \\
\hline 38 & G. J. Rogers \\
\hline 39 & F. H. Shade 1 \\
\hline 40 & J. A. Stoddard \\
\hline 41 & K. G. Toyoda \\
\hline 42 & R. F. Warnick \\
\hline
\end{tabular}


ONSITE DISTRIBUTION (contd.)

Copy Number

43

44

45-49

50

51

Richland Operations Office

52

53
N. G. Wittenbrock

K. L. Young

Technical Information Files

Technical Pub1ications, 300 Area

Technical Publications, 700 Area

R. K. Sharp

Technical Information Library 